\title{
KRIŽNA JAMA (SW SLOVENIA): NUMERICAL- AND CORRELATED-AGES FROM CAVE BEAR-BEARING SEDIMENTS
}

\author{
PRIMERJAVA ŠTEVILČNE IN KORELIRANE STAROSTI \\ SEDIMENTOV Z OSTANKI JAMSKEGA MEDVEDA V KRIŽNI JAMI
}

\author{
Pavel BOSÁK ${ }^{1,2}$, Petr PRUNER ${ }^{1}$, Nadja ZUPAN HAJNA², Helena HERCMAN ${ }^{3}$, \\ Andrej MIHEVC ${ }^{2} \&$ Jan WAGNER ${ }^{1}$
}

\begin{abstract}
UDC 902.03:551.435.84(497.4 Križna jama) Pavel Bosák, Petr Pruner, Nadja Zupan Hajna, Helena Hercman, Andrej Mihevc \& Jan Wagner: Križna jama (SW Slovenia): Numerical-and correlated-ages from Cave Bear-bearing sediments

Križna jama is a large river cave located between Loško and Cerkniško poljes under Križna gora Mount in southern Slovenia. It has been known since the mid-19 $9^{\text {th }}$ century due to numerous cave bear finds. The cave is filled by complicated sequences of cave fluvial and lacustrine sediments, which are recently partly eroded. We studied two paleontological excavations and profiles in the Medvedji rov to contribute to the solution of dating of bone-bearing lithological horizons. The Križna jama I profile consists of alternation of speleothem layers (flowstone sheets with small stalagmites, sometimes with in situ cemented Ursus gr. spelaeus bones) and fine-grained siliciclastics often with bones of cave bear. It can be correlated with the upper part of the Križna jama II profile, but with a slightly less preserved stratigraphic record. Radiocarbon and U-series dates clearly indicate two different ages of cave bear thanatocenoses in the Križna jama I profile: those above flowstone crusts were dated to ca. $47-45 \mathrm{ka}$ by radiocarbon dating; those included in speleothem layers and clay interbeds are older than $94 \mathrm{ka}$ (U-series date). The details of internal lithology, low thicknesses of layers and the state of bone preservation exclude expected sandwiching of younger layers into eroded/washed spaces among flowstones. Numerical dating excludes re-deposition of bear bones from older assemblage to sediments above flowstones. According to the paleomagnetic parameters (prevailing normal polarization), the deposition took place within
\end{abstract}

Izvleček UDK 902.03:551.435.84(497.4 Križna jama) Pavel Bosák, Petr Pruner, Nadja Zupan Hajna, Helena Hercman, Andrej Mihevc \& Jan Wagner: Primerjava številčne in korelirane starosti sedimentov $z$ ostanki jamskega medveda $v$ Križni jami

Križna jama je znana vodna jama med Loškim in Cerkniškim poljem v južni Sloveniji. Jama, ki je poznana od sredine 19. stoletja, slovi zaradi številnih najdb ostankov jamskega medveda. $\mathrm{V}$ jami so se $\mathrm{v}$ zaporedjih odlagali fluvialnih in jezerski sedimenti, ki so bili kasneje tudi delno erodirani. V Medvedjem rovu smo proučevali dve lokaciji preteklih paleontoloških izkopavanj $\mathrm{z}$ namenom ponovne datacije plasti s kostmi. Profil Križna jama I sestavljajo menjajoče se plasti sige (plasti sige $\mathrm{z}$ majhnimi stalagmiti, včasih $\mathrm{z}$ in situ cementiranimi kostmi Ursus gr. Spelaeus v zgornjem delu profila) in drobnozrnate siliciklastične naplavine pod plastmi sige, ki tudi vsebujejo ostanke jamskega medveda. Profil je primerljiv z zgornjim delom profila Križna jama II, ki pa ima malo slabše ohranjen stratigrafski zapis. Rezultati datacij $\mathrm{z}$ radiokarbonsko in U/Th metodo jasno kažejo dve različni starosti tanatocenoze jamskega medveda iz profila Križna jama I: prva so kosti nad plastjo sige, ki je bila datirana $\mathrm{z}$ radiokarbonsko metodo na ca. 47-45 ka; druga so kosti v plasteh sige $\mathrm{z}$ vmesnimi plastmi gline, ki so starejše od 94 ka (U-serija). Podrobnosti v litologiji, tankost plasti in stanje ohranjenosti kosti, izključujejo možnost mlajše sedimentacije v erodirane/izprane praznine med sigovimi plastmi. Numerične datacije tudi izključujejo presedimentacijo medvedjih kosti iz starejših plasti v sedimente nad sigo. Glede na paleomagnetne rezultate (prevladuje normalna polarizacija), se je sedimentacija dogajala v Brunhes obdobju $(<780 \mathrm{ka})$. Odkrite so bile tudi

\footnotetext{
${ }^{1}$ Institute of Geology of the Academy of Sciences of the Czech Republic, v. v. i., Rozvojová 269, 16500 Praha 6, Czech Republic, e-mail: bosak@gli.cas.cz,pruner@gli.cas.cz,wagner@gli.cas.cz

${ }^{2}$ Karst Research Institute, Scientific Research Centre, Slovenian Academy of Sciences and Arts, Titov trg 2, 6230 Postojna, Slovenia, e-mail: zupan@zrc-sazu.si,mihevc@zrc-sazu.si

${ }^{3}$ Institute of Geological Sciences, Polish Academy of Sciences, ul. Twarda 51/55, 00-818 Warszawa, Poland, e-mail: hercman@twarda.pan.pl
}

Received/Prejeto: 06.09.2010 
the Brunhes Chron ( $<780 \mathrm{ka})$. There were discovered in total four short-lived reverse excursions of the magnetic field. According to U-series data, the upper one (profile I) might be correlated with the Blake excursion. The lower ones are older than ca $190 \mathrm{ka}$ and can be correlated with some of the JamaicaPringle Falls, Namaku, Calabrian Ridge, Portuguese margin or Calabrian Ridge 1 excursions. Sediments in studied profiles were deposited during the Last Glacial (Weichselian), Eemian interglacial, Saalian glacial and Holsteinian interglacial.

Keywords: magnetostratigraphy, U-series dating, bear cave, Middle/Late Pleistocene. štiri kratkotrajne magnetne reverzne ekskurzije. Glede na podatke pridobljene $\mathrm{z}$ U-serijo, bi lahko zgornjo ekskurzijo (profil Križna jama I) povezali z Blake ekskurzijo. Nižje ležeči obrati/ ekskurzije so pa starejši od ca. $190 \mathrm{ka}$ in bi jih zato lahko primerjali z nekaterimi od naslednjih znanih ekskurzij: JamaicaPringle Falls, Namaku, Calabrian Ridge, Portuguese margin ali Calabrian Ridge 1. Sedimenti v raziskovanih dveh profilih so bili odloženi v zadnjem glacialu (Weichselian/Würm), Eemianskem interglacialu (Riss - Würm), Saalianskem glacialu (Riss) in Holsteinianskem interglacialu (Mindel - Riss).

Ključne besede: magnetostratigrafija, radiometrično datiranje, jamski medved, srednji in pozni pleistocen.

\section{INTRODUCTION}

The first notes about Križna jama (Cave; Kreuzberghöhle, Cross Cave, Merzla jama) are recorded in the diary of J. J. Tobin from 1828 (Shaw 1979; Bavdek et al. 2009), but it seems that this cave was already known to Johann Weichard Valvasor, a historiographer in the $17^{\text {th }}$ century, who spoke about three caves near Šteberk castle (Bavdek et al. 2009). The cave has been known especially for its paleontological content (e.g. Schmidl 1854; Hochstetter 1882a, Michler 1934a, b; Soergel 1940; Šerko \& Michler 1948, 1958).

Zörrer (1838; also known as Cerar) published, for the first time, a detailed description of known parts of the cave, and he presented the first cave map from 1825 (see Hochstetter 1880, p. 536); however he mentioned no fossil remains. Later, a more popular description of the cave was given by Skoffiz (1847a-d; written as Skofitz in Schmidl 1854 or Skofiz in Hochstetter 1882a), who mentioned the presence of cave bear remains for the first time (Skoffiz 1847d). Schmidl (1854) described the cave and the large amount of fossil bones (some mistakes concerning the cave and bear remains were corrected by Hochstetter 1882a), for which, as the first, he used the scientific name Ursus spelaeus. Schmidl (1863, p. 114) mentioned the Kreuzberghöhle as a typical case of a "bear cave".

Nevertheless, the first scientific excavations were undertaken only by Ferdinand v. Hochstetter in 1878 and 1879. Hochstetter (1879a) reported briefly about his first excavation in Kreuzberghöhle in 1878. In addition to the large number of cave bear bones (at least from 40-50 individuals, but most probably from more than 100 individuals), he noted also the presence of non-ursid rests and coprolites of cave hyena. In later papers (Hochstetter $1880,1882 \mathrm{a}, \mathrm{b})$, he reported only the presence of concretions that could be easily confused with hyena's coprolites. Two complete cave bear skeletons were assembled from excavated bones (Hauer 1879, p. 12; Hochstetter 1882a).
During the second excavation in 1879, Hochstetter was accompanied by Josef Szombathy and Ernst Kittl. Detailed maps of the cave and its surroundings were provided (Hochstetter 1879b, 1880, 1881a, b, 1882a, b). Excavations in 1879 were performed at three sites inside the cave: one in Kittlovo brezno (Kittl's Bärenhöhle in Hochstetter 1882a [discovered in 1879]; Mala medvedja jama in Badiura 1909; Kittl's Bear Gallery or Kittlova medvedja dvorana in Pohar et al. 2002) and two in Medvedji rov (Hochstetter's Schatzkammer with Bärenwirthshaus [the main excavated area in both 1878 and 1879], and Hauer's Fundplatz in Hochstetter 1882a; Velika medvedja jama in Badiura 1909; The Bear's Gallery in Gospodarič 1974; Bear Passage in Ford \& Gospodaric 1989). A colored map of the cave with sections and profiles was compiled by J. Szombathy in August 1879 (1:1,000; Hochstetter 1879b, etc.; Južnič 2006) and the map of cave surroundings by E. Kittl $(1: 10,000$; Hochstetter 1879b, etc.), both published in Hochstetter (1881b, 1882a) for the first time. In addition to these maps, several sections and profiles were drawn, from which the section with Hochstetter's Schatzkammer was already published in Hochstetter (1880; with a little more detail than in later papers).

Although Križna jama has remained a well-known "bear cave" since Hochstetter's publication (Szombathy 1883 ex Gratzy 1897; Badiura 1909; Michler 1934a, b; Soergel 1940, p. 42; Cramer 1941, p. 397) and was included in many catalogues and summarized papers (Gratzy 1897; Wolf 1939; Šerko \& Michler 1948, 1958; Rakovec 1956, 1975; Musil 1980, p. 57), there were no new excavations till the second half of the $20^{\text {th }}$ century. Bones deposited in clay inter-beds among flowstone sheets were studied later by Brodar and Gospodarič (1973), Gospodarič (1974), Rabeder and Withalm (2001), Pohar et al. (2002), Rabeder et al. (2008) and Rabeder (2009). Flowstones from Brodar and Gospodarič (1973) 
pit in Hochstetter's Schatzkammer (Hauer's Fundplatz) were dated by Ford and Gospodarič (1989).

Uncertainty concerning the age of bear bones resulted from the radiometric data. Those obtained by U-series dating of flowstones by Ford and Gospodarič (1989) indicate ages of 126 to $173 \mathrm{ka}$. Radiocarbon dates from overlying bone-bearing clays originally presented by Rabeder and Withalm (2001) indicate much younger ages, around $45 \mathrm{ka}$. We studied the site with the aim to (1) contribute to dating of bone-bearing lithological horizons and (2) search for short reverse Blake excursion in normal polarized Brunhes Chron (117.1 \pm 1.2 to 111.8 \pm 1.0 ka BP; Løvlie 1989; Zhu et al. 1994).

\section{SITE LOCATION AND CHARACTERISTICS}

Križna jama (Reg. No. 65 in the Cave Register of the Speleological Association of Slovenia; location of the entrance: $45^{\circ} 44^{\prime} 42.70^{\prime \prime} \mathrm{N} ; 14^{\circ} 28^{\prime} 02.18^{\prime \prime} \mathrm{E}$; entrance at $629 \mathrm{~m}$ asl; Fig. 1) is a large river cave $8,273 \mathrm{~m}$ long. It is situated in the area between Loško and Cerkniško poljes under Križna gora Mount (856 m asl; Fig. 1). Karst above the cave is developed in the belt of lower relief that formed in the Idrija fault zone between two karst poljes: Loško polje on the southeast with a floor at about $570 \mathrm{~m}$ asl and Cerkniško polje on the northwest at about $550 \mathrm{~m}$ asl (Fig. 1). The relief above the cave is characterized by conical hills rising 150-200 $\mathrm{m}$ above closed depressions,

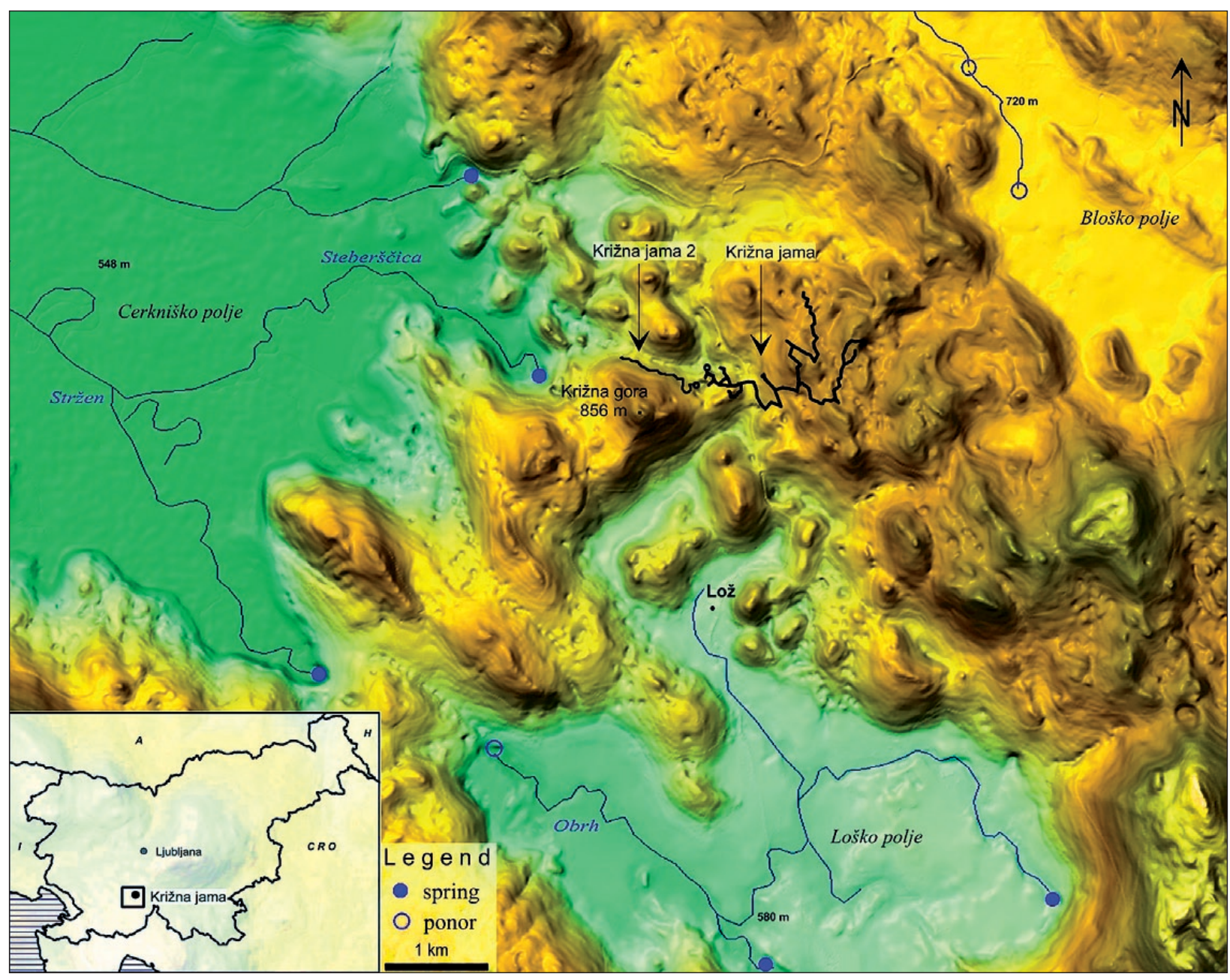

Fig. 1: Digital elevation model of a part of the Notranjski kras (southern Slovenia) with karst poljes along the Idrija fault zone, and location of Križna jama and Križna jama 2 caves (DEM source: DMV 12.5 m, Geodetska uprava Republike Slovenije). 
dolines, uvalas and small polje-like levelled surfaces. Levelled surfaces are developed at the same altitude as Cerkniško polje, where important karst springs are located. The cave entrance is situated in an elongated karst depression to the east of Križna gora. There are numerous shafts and caves; two compose a large cave system - Križna jama and its SW continuation Križna jama 2 (New Križna jama) - some $10 \mathrm{~km}$ long. The caves are separated by an approximately $240 \mathrm{~m}$ long sump.

The cave is developed in Liassic/Doggerian limestones with dolomitic lenses. The beds dip towards the south to southeast at $20^{\circ}$ (Buser et al. 1967). Passages are mainly developed along bedding planes and some of them follow $\mathrm{N}-\mathrm{S}$-trending tectonic structures (Gospodarič 1974).

Križna jama is a cave system with an extensive principal passage and tributaries. The active water passages are located at about $610 \mathrm{~m}$ asl. The older passages are slightly higher, between 620 and $640 \mathrm{~m}$ asl. An underground river flows in from Bloško polje, then dis- appears into deep sumps, continues westwards into Križna jama 2, and reappears in Šteberščica spring at the SE edge of Cerkniško polje (Novak 1966, 1969; Kogovšek et al. 2008). The cave was formed in rather stable conditions between the Cerkniško and Loško poljes, as indicated by the mostly epiphreatic conditions of passage evolution.

Remains of fluvial sediments are preserved throughout the entire cave, indicating that it was filled by more sediments in the past (Gospodaric 1974). The Medvedji rov represents one of such older passages, $325 \mathrm{~m}$ long and situated ca. $15 \mathrm{~m}$ above the active stream. In the past, it was connected to the main passage at both ends, but at present the entrance from Cerarjeva dvorana (Cerar [Zörrer] Hall) is blocked by a huge speleothem (Fig. 2, upper left in detail). Different fluvial sediments and speleothems fill the passage almost to the ceiling in places. In some parts they have been eroded away. The most detailed study of fluvial sediments was done by Gospodarič (1974).

\section{METHODS}

\section{PALEOMAGNETIC ANALYSIS}

Paleomagnetic analyses were completed in the Laboratory of Paleomagnetism, IG AS CR in Praha-Průhonice, Czech Republic. All field hand specimens were oriented in situ. Unconsolidated sediments were sampled in standard, non-magnetic plastic boxes (size $20 \times 20 \times 20 \mathrm{~mm}$, volume about $6.7 \mathrm{~cm}^{3}$; Natsuhara Giken Ltd., Japan). Samples from consolidated rocks and speleothems were collected from the profile in large pieces, which were cut in the laboratory into cubes of $20 \times 20 \times 20 \mathrm{~mm}$. The natural remanent magnetization (NRM) of flowstones and clays was measured either using a JR-5A spinner magnetometer or a 3-axis 2-G liquid-helium free superconducting rock magnetometer (type $7554 \mathrm{~K} \mathrm{SRM}$ ). The magnetic susceptibility $(k)$ of specimens was determined using a KLY-2 (or KLY-3) Kappabridge (Jelínek 1966, 1973). Samples were demagnetized by the alternating field (AF) using either a LDA-3A or SRM alternating field demagnetizer. A portion of the flowstones were also subjected to progressive thermal demagnetization (TD) using the MAVACS demagnetizer (Př́hoda et al. 1989). Results of measurements were analyzed using the software package Remasof (Chadima \& Hrouda 2006). Based on the pilot results, each of the samples collected were either AF or TD demagnetized in 12-16 AF fields or heating steps. All data were looked at using vector endpoint or Zijderveld plots and $M / M_{n}$ versus laboratory AF demagnetization fields or temperature. Individual components of magnetization were determined using principal component analysis (Kirschvink 1980). During thermal magnetization, the $k$ was additionally measured using a KLF-4A Automatic Magnetic Susceptibility Meter (Jelínek 1966, 1973) and plotted after each thermal step to monitor possible phase changes in the magnetic minerals as a result of heating.

Results of paleomagnetic analyses, including values and mean values of the MS, NRM, D, I, discussion of primary data, and paleomagnetic profiles were summarized by Zupan Hajna et al. (2008b).

\section{X-RAY POWDER DIFFRACTION ANALYSES}

$\mathrm{X}$-ray powder diffraction analyses were performed in (1) the Laboratory of Physical Methods, IG AS CR in Praha (analysts Dr. Roman Skála and Mr. Jiří Dobrovolný); all powder patterns were collected with a Philips X'Pert APD diffractometer $(\mathrm{Cu}$ and $\mathrm{Co}$ radiation, graphite monochromator, $40 \mathrm{kV}, 32$ or $40 \mathrm{~mA}$ ). For each specimen four individual sets of pattern were acquired for: randomly-oriented material, oriented specimens, glycolated specimens, and samples heated to $400^{\circ} \mathrm{C}$ under ambient atmosphere, and (2) at the Geological Institute of Faculty of Natural Sciences and Engineering in Ljubljana (ana- 
lyst Dr. Meta Dobnikar); the qualitative mineral composition was determined by X-ray powder diffraction with a Philips diffractometer (anode $\mathrm{CuK}_{\alpha}, 40 \mathrm{kV}, 30 \mathrm{~mA}$ and $\mathrm{Ni}$ filter). The concentrations of minerals were determined from the height of the main reflection of each particular mineral in the X-ray record.

\section{U-SERIES DATING}

New U-series analyses based on alpha particle spectrometry were performed in the Geochronology Laboratory, Institute of Geological Sciences, Polish Academy of Sci- ences in Warsaw (analysts Dr. Helena Hercman and Dr. Tomasz Nowicki). Standard chemical procedures for uranium and thorium separation from carbonate samples were used (Ivanovich \& Harmon 1992). The activity was measured using an ORTEC OCTETE counting utility with silica barrier detections. Analyses of spectra energy and age calculations were made with the URANOTHOR 2.5 software, which is the standard software currently used in the Geochronology Laboratory in Warsaw (Gorka \& Hercman 2002). The quoted age errors are one standard deviation based on counting statistics.

\section{SEDIMENTARY PROFILES}

Two profiles in the Medvedji rov were investigated (Fig. 2). The first, studied in 2003, was focused on sampling of speleothems and sediments from the profile of Ford and Gospodarič (1989) in a small pit (Križna jama I profile; situated in Hochstetter's Schatzkammer in the place signed as Die Drei Säulen) on the northern side of the small chamber (Fig. 2). In 2004 and 2005, we sampled a much thicker profile (Križna jama II pro-

\section{KRIŽNA JAMA I}

The Križna jama I profile (Figs. 3b \& 4) was sampled in the small pit dug out during archaeological and paleontological studies in 1971 by Mitja Brodar and Rado Gospodarič (original size: $2 \mathrm{~m}$ wide and $1 \mathrm{~m}$ deep; Brodar \& Gospodarič 1973). For the first time they found Ursus gr. spelaeus bones below flowstone layers (Brodar \& Gospodarič 1973, fig. on p. 41); Hochstetter (1882a, pp. 303 \& 305) described cave bear bones covered by young flowstone crust on the top of the profile in Hauer's Fundplatz and below the Monumentenhügel stalagmite. Brodar and Gospodarič (1973, pp. 33-35, fig. on p. 41) studied another section, $15 \mathrm{~m}$ wide and up to $5 \mathrm{~m}$ deep, situated several meters $\mathrm{N}$ of the pit with identical stratigraphy as in the pit. Flowstones were later sampled by Ford and Gospodarič (1989) for U-series dating (Fig. 3a).

The documented profile differs from a drawing of Bro- file; Hochstetter's Bärenwirthshaus) on the southern side of the same chamber, about 20-30 m away (Fig. 2). Both profiles are separated by a deep erosional hole (an underground subsidence doline) probably caused by oscillating water levels in the lower passage of Križna jama. dar and Gospodarič (1973, p. 41) and of R. Gospodarič from 1982 (published in Ford \& Gospodarič 1989). The changes were caused by continued paleontological excavations (cf. Rabeder \& Withalm 2001; Pohar et al. 2002). For our sampling in 2003, we used the unchanged pit as left after previous paleontological excavations (Pruner et al. 2004). We preserved all speleothem and sediment hori- 


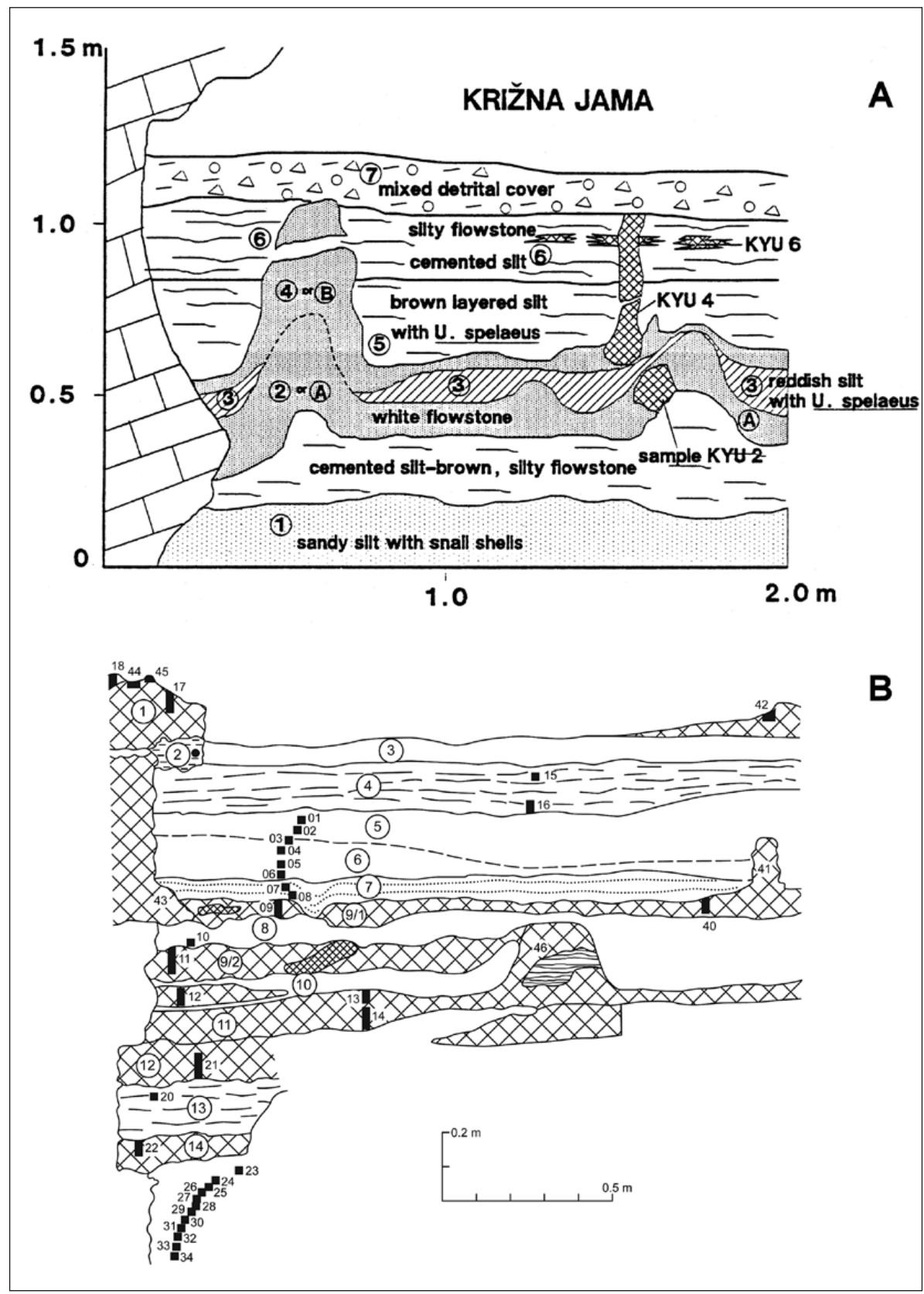

Fig. 3: Križna jama I profile. a) profile drawing by Ford and Gospodarič (1989; with permission); b) state of profile in 2003 and 2004. Legend: numbers in circles indicate the number of the layer; black squares with numbers indicate paleomagnetic samples.

zons, including bear bone-bearing speleothems, as a control profile. Further changes of the pit were documented in 2004: flowstones with bear bones disappeared and the shape and size of the pit changed and enlarged substantially, probably by continued paleontological excavations.

\section{Lithology}

The excavated pit uncovered a sequence of flowstones with stalagmites alternating with clays and silts, and un- derlain by silts (Figs. $3 b$ \& 4 ; Tab. 1).

Ford and Gospodarič (1989) layer No. 3 was much thicker and uniform in lithology (reddish silt with bones of Ursus gr. spelaeus) in the profile documented by R. Gospodarič in 1982. Continued later excavations changed it to alternation of clays and flowstones, as documented by us in 2003 and 2004. Our layer No. 9/2 was not exposed within layer No. 3 of Ford and Gospodarič (1989). Layers 9/1, 8, 9/2 and 10 contained bear bones in 2003 (Figs. 3b \& 4). Snails reported in the bottom part of the profile (layer No. 1 of Ford \& Gospodarič 1989) were not found. A comparison of both stratigraphies is given in Tab. 1.

\section{Mineralogy}

The sterile yellow clays (without Ursus gr. spelaeus bones) below the bottom of the small pit were analyzed by $\mathrm{X}$-ray diffraction: quartz prevailed; muscovite, chlorite, some kaolinite and mixed layered chlorite/montmorillonite were also present. Brown to red clays above speleothems had almost the same mineral composition, except for plagioclase present there in the traces. Brodar and Gospodarič (1973) from a wide profile $\mathrm{N}$ of the pit mentioned quartz grains (up to $60 \%$ in some laminas) and limonite ooids and hematite crystals (up to 39\%) in all layers, and bauxite ooids (max. $1 \%$ ) and green mica (max. 1\%) in individual layers.

\section{Paleomagnetic results}

A total of 43 samples were studied for their paleomagnetic properties. They are characterized by high scatter of the NRM intensities (0.45-56 mA.m $\left.{ }^{-1}\right)$ and MS values (-4-414 x $10^{-6}$ SI units), and by very low up to interme- 
Tab. 1: Description of Križna jama I profile (from top to bottom; see Fig. 3B).

\begin{tabular}{|c|c|c|c|}
\hline Meters & $\begin{array}{l}\text { Layer } \\
\text { No. }\end{array}$ & Description & $\begin{array}{l}\text { Layer } \\
\text { No. after F\&G* }\end{array}$ \\
\hline $0.00-0.17$ & 1 & Speleothem, white, crystalline, laminated & 4 (B) cap \\
\hline $0.17-0.28$ & 2 & Speleothem, brown, laminated, locally with laminas of clay & \\
\hline $0.79-1.18$ & 3 & Loam, redeposited/reworked by excavation & 7 \\
\hline $0.28-0.40$ & 4 & $\begin{array}{l}\text { Speleothem, beige, laminated, hard laminas alternate with soft ones (moonmilk-like), } \\
\text { bands of clay appear towards right }\end{array}$ & 6 \\
\hline $0.40-0.45$ & 5 & $\begin{array}{l}\text { Clay, brown, laminated, with fine mica, with laminas to thin bands of chocolate brown } \\
\text { clays }\end{array}$ & 6 \\
\hline $0.45-0.60$ & 6 & Loam, clayey, brown, locally with vario-colored and dark stains & 5 \\
\hline $0.60-0.65$ & 7 & $\begin{array}{l}\text { Clay, brown, laminated, slightly with fine mica, locally with manganese coatings on } \\
\text { bedding planes }\end{array}$ & 5 \\
\hline $0.62-0.72$ & 9/1 & Speleothem with cave bear bones & $4(\mathrm{~B})$ \\
\hline $0.65-0.75$ & 8 & $\begin{array}{l}\text { Clay, yellowish to reddish brown, laminated, with fine mica, at middle breccia, } \\
\text { ferruginized, locally carbonate cemented }\end{array}$ & 3 \\
\hline $0.75-0.89$ & $9 / 2$ & Speleothem with cave bear bones & $2(\mathrm{~A})$ \\
\hline 0.89-0.95 & 10 & Clay, brown, irregularly cemented by carbonate & 3 \\
\hline $0.95-1.07$ & 11 & $\begin{array}{l}\text { Speleothem, in upper part divided by clay lamina. Upper part thinning towards right. } \\
\text { Lower part is laminated }\end{array}$ & $2(A)$ \\
\hline $1.07-1.25$ & 12 & Speleothem, rather brown, transition to carbonate-cemented loam & $2(\mathrm{~A})$ \\
\hline $1.25-1.40$ & 13 & $\begin{array}{l}\text { Loam, irregularly cemented by carbonate, with mud cracks, alternation with thin layers } \\
\text { of flowstone }\end{array}$ & $2(A)$ \\
\hline $1.40-1.50$ & 14 & Speleothem, rather brown, transition to carbonate-cemented loam & \\
\hline $1.50-1.80$ & 15 & Clay, yellowish brown, irregularly columnar, with $\mathrm{Mn}+\mathrm{Fe}-$ rich coatings on fissures & 1 \\
\hline
\end{tabular}

${ }^{*}$ F\&G - Ford and Gospodarič (1989; Fig. 1 on p. 42)

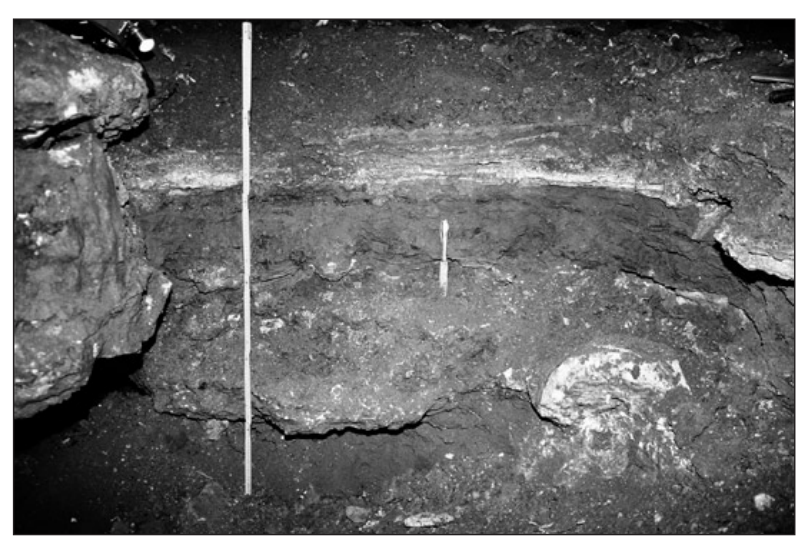

Fig. 4: The upper part of the Križna jama I profile in 2003; the white stalagmite on the right side of the photo corresponds to number 46 in Fig. 3 A (Digitized slide; photo: P. Bosák).

diate $J_{\mathrm{n}}$ and $k_{\mathrm{n}}$ magnetic values. Mean $J_{\mathrm{n}}$ and $k_{\mathrm{n}}$ moduli values are summarized in Tab. 2. According to both values, the profile may be divided into two parts, clays and flowstones (Tab. 2).

All samples were subjected to detailed AF and/or TD demagnetization. Paleomagnetic samples generally showed very well-behaved demagnetization paths that converge on the origin, losing over $90 \%$ of the sample intensity during the AF demagnetization to $100 \mathrm{mT}$ or $560^{\circ} \mathrm{C}$ with the TD. Representative TD results from one
Tab. 2: Mean value and standard deviation of the NRM and volume MS.

\begin{tabular}{|c|c|c|c|}
\hline Križna jama I & $\begin{array}{c}J_{n} \\
{\left[m A \cdot m^{-1}\right]}\end{array}$ & $\begin{array}{c}k n \times 10^{-6} \\
{[S I]}\end{array}$ & Rock \\
\hline Mean value & 10.789 & 270.8 & \multirow{3}{*}{ clays } \\
\hline Standard deviation & 5.812 & 47.0 & \\
\hline Number of samples & 22 & 22 & \\
\hline Mean value & 9.425 & 107.8 & \multirow{3}{*}{ flowstones } \\
\hline Standard deviation & 13.744 & 119.8 & \\
\hline Number of samples & 21 & 21 & \\
\hline Mean value & 10.122 & 191.2 & \multirow{3}{*}{ summary } \\
\hline Standard deviation & 10.488 & 121.5 & \\
\hline Number of samples & 43 & 43 & \\
\hline
\end{tabular}

flowstone sample of reverse $(\mathrm{R})$ polarity (sample $\mathrm{K} 11 \mathrm{~B}$ from $0.84 \mathrm{~m}$ ) and one sample with normal $(\mathrm{N})$ polarity (K 17B from $0.13 \mathrm{~m}$ ) are shown in Figs. 5a and 5b. Average unblocking temperatures of $560^{\circ} \mathrm{C}$ point to magnetite as the principal carrier of magnetization. Examples of AF demagnetization results are illustrated in Figs. $5 \mathrm{c}$ and $5 \mathrm{~d}$ for samples with $\mathrm{R}$ polarity directions (sample K 11A2 from $0.79 \mathrm{~m}$ ) and samples with the $\mathrm{N}$ polarity directions (K 20 from $1.30 \mathrm{~m}$ ). Results of the multi-component analysis of remanence (Kirschvink 1980) show that samples display two or three directional components. The 
Tab. 3: Mean paleomagnetic directions of samples.

\begin{tabular}{|c|c|c|c|c|c|c|}
\hline \multirow[t]{4}{*}{$\begin{array}{l}\text { Križna } \\
\text { jamal }\end{array}$} & \multirow[t]{2}{*}{ Polarity } & \multicolumn{2}{|c|}{$\begin{array}{c}\text { Mean paleomagnetic } \\
\text { Directions }\end{array}$} & \multirow{2}{*}{$\begin{array}{c}a_{95} \\
{[0]}\end{array}$} & \multirow[t]{2}{*}{$k$} & \multirow[t]{2}{*}{$n$} \\
\hline & & $D\left[{ }^{\circ}\right]$ & $I[\circ]$ & & & \\
\hline & $\mathrm{N}$ & 350.76 & 61.32 & 6.85 & 12.29 & 34 \\
\hline & $\mathrm{R}$ & 204.17 & -37.64 & 30.74 & 1.89 & 11 \\
\hline
\end{tabular}

Note: $\mathrm{N}$ - normal polarity, $\mathrm{R}$ - reverse polarity; $\mathrm{D}, \mathrm{I}$ - declination and inclination of the remanent magnetization; $\alpha_{95}$ - semi-vertical angle of the cone of confidence calculated according to Fisher (1953) at the $95 \%$ probability level; $\mathrm{k}$ - precision parameter; $\mathrm{n}$ - number of analyzed samples.

Tab. 4: Mean paleomagnetic directions, Križna jama I.

\begin{tabular}{|c|c|c|c|c|c|c|}
\hline \multirow[t]{2}{*}{ Sample No. } & \multirow[t]{2}{*}{ Polarity } & \multicolumn{2}{|c|}{$\begin{array}{c}\text { Mean paleomagnetic } \\
\text { directions }\end{array}$} & \multirow{2}{*}{$\begin{array}{c}a_{95} \\
\left.{ }^{\circ}\right]\end{array}$} & \multirow[t]{2}{*}{$k$} & \multirow[t]{2}{*}{$N$} \\
\hline & & $D\left[{ }^{\circ}\right]$ & $I\left[^{\circ}\right]$ & & & \\
\hline K 1-10, 15-18 & $\mathrm{N}$ & 6.60 & 56.52 & 5.22 & 44.93 & 16 \\
\hline K 11 & $\mathrm{R}$ & 75.63 & -39.81 & 8.83 & 62.89 & 4 \\
\hline K 12-14, 20-23 & $\mathrm{N}$ & 342.77 & 46.75 & 13.25 & 11.17 & 10 \\
\hline K 24-30 & $\mathrm{R}(\mathrm{R}+\mathrm{N})$ & 224.52 & -7.91 & 7.00 & 57.18 & 7 \\
\hline K 24, 28-34 & $\mathrm{N}(\mathrm{N}+\mathrm{R})$ & 278.56 & 78.57 & 6.83 & 52.49 & 8 \\
\hline
\end{tabular}

Note: see Tab. 3. that were subjected both to TD and AF demagnetization have given identical results from specimens belonging to the same sample of the same layer.

The mean direction and associated dispersion parameters of the C-components were calculated using Fisher statistics (Fisher 1953) and are shown in Fig. 6 and Tab. 3 along with their associated circles of $95 \%$ confidence. The mean paleomagnetic directions of normal polarized C-components for profile I are $\mathrm{D}=351^{\circ}, \mathrm{I}=61^{\circ}$, and of $\mathrm{R}$ polarized $\mathrm{C}$-components are $\mathrm{D}=204^{\circ}, \mathrm{I}=-38^{\circ}$. The Fisher distribution displays more than two distinct dis-

Tab. 5: Th/U dating results using $\alpha$-spectrometry from speleothems, profile Križna jama I (according to stratigraphic order).

\begin{tabular}{|c|c|c|c|c|c|c|c|c|}
\hline $\begin{array}{l}\text { Sample } \\
\text { No. }\end{array}$ & $\begin{array}{l}\text { Lab. } \\
\text { No. }\end{array}$ & $\begin{array}{l}U \text { content } \\
\text { [ppm] }\end{array}$ & ${ }^{234} U /{ }^{238} U$ & ${ }^{230} \mathrm{Th} /{ }^{234} \mathrm{U}$ & ${ }^{230} \mathrm{Th} /{ }^{332} \mathrm{Th}$ & $\begin{array}{l}\text { Age } \\
\text { [ka] }\end{array}$ & Remarks & Layer* \\
\hline $\mathrm{K} 42 / 1$ & $\begin{array}{l}W \\
1555\end{array}$ & $0.0787 \pm 0.0055$ & $1.2320 \pm 0.1034$ & $0.7831 \pm 0.0664$ & $3.7 \pm 0.5$ & & $\begin{array}{l}\text { Detrital Th } \\
\text { contamination }\end{array}$ & $\begin{array}{c}\text { above } \\
3\end{array}$ \\
\hline K 45 & $\begin{array}{l}W \\
1533\end{array}$ & $0.1262 \pm 0.0064$ & $1.3466 \pm 0.0772$ & $0.5969 \pm 0.0365$ & $46 \pm 17$ & $\begin{array}{c}+8.3 \\
93.8 \\
-7.8\end{array}$ & & $9 / 1$ \\
\hline K 43 & $\begin{array}{l}W \\
1532\end{array}$ & $0.0460 \pm 0.0035$ & $1.2165 \pm 0.1182$ & $1.1679 \pm 0.1040$ & $2.4 \pm 0.3$ & & $\begin{array}{l}\text { Detrital Th } \\
\text { contamination }\end{array}$ & $9 / 1$ \\
\hline $\begin{array}{l}\mathrm{K} 41 \\
\text { middle }\end{array}$ & $\begin{array}{l}\text { W } \\
1615\end{array}$ & $0.0389 \pm 0.0026$ & $1.2007 \pm 0.1039$ & $0.7373 \pm 0.0662$ & $22 \pm 8$ & $137_{-19}^{+22}$ & & $9 / 1$ \\
\hline $\begin{array}{l}\text { K } 41 \\
\text { lower } \\
\text { part }\end{array}$ & $\begin{array}{l}\text { W } \\
1616\end{array}$ & $0.4292 \pm 0.0145$ & $0.9955 \pm 0.0270$ & $0.0949 \pm 0.0062$ & $20 \pm 6$ & $\begin{array}{c}+0.8 \\
-0.8\end{array}$ & $\begin{array}{l}\text { Open system or } \\
\text { younger calcite } \\
\text { precipitation }\end{array}$ & $9 / 1$ \\
\hline $\mathrm{K} 46$ & $\begin{array}{l}W \\
1617\end{array}$ & $0.0266 \pm 0.0040$ & $1.2252 \pm 0.2192$ & $0.6829 \pm 0.1287$ & $20 \pm 13$ & $1_{-31}^{+39}$ & & 11 \\
\hline
\end{tabular}

${ }^{\star}$ See Fig. 3b.

A-component is undoubtedly of viscous origin and can be demagnetized at $20-60^{\circ} \mathrm{C}$ or $2-5 \mathrm{mT}$. The $B$-low field component (B-LFC) and/or B-low temperature component $(B-L T C)$ are also secondary; they show harder magnetic properties and can be demagnetized in the AF (5-10 to $15 \mathrm{mT}$ ) or in a temperature range of 120 to (300) $400^{\circ} \mathrm{C}$. The characteristic C-high field component (C-HFC) and/ or C-high temperature component (C-HTC) is the most stable, with a temperature-range of demagnetization at ca. $300-520(550){ }^{\circ} \mathrm{C}$ or $15-80$ (100) mT. Speleothems tribution-defined sets of samples with $\mathrm{N}$ and $\mathrm{R}(\mathrm{R}+\mathrm{N})$ polarities. Based on mean paleomagnetic directions ( $D$ and I), the profile was divided into five intervals (Tab. 4). Flowstone samples with $\mathrm{R}$ polarity directions from layer No. 9 (sample K 11) reveal anomalously paleomagnetic declination, and clay samples with $\mathrm{R}$ polarity directions from interval 1.52-1.64 $\mathrm{m}$ display anomalously low mean values of paleomagnetic inclination (Tab. 4).

The basic magnetic parameters are documented in Fig. 7. Short R polarized magnetozones in $0.76-0.88$ 

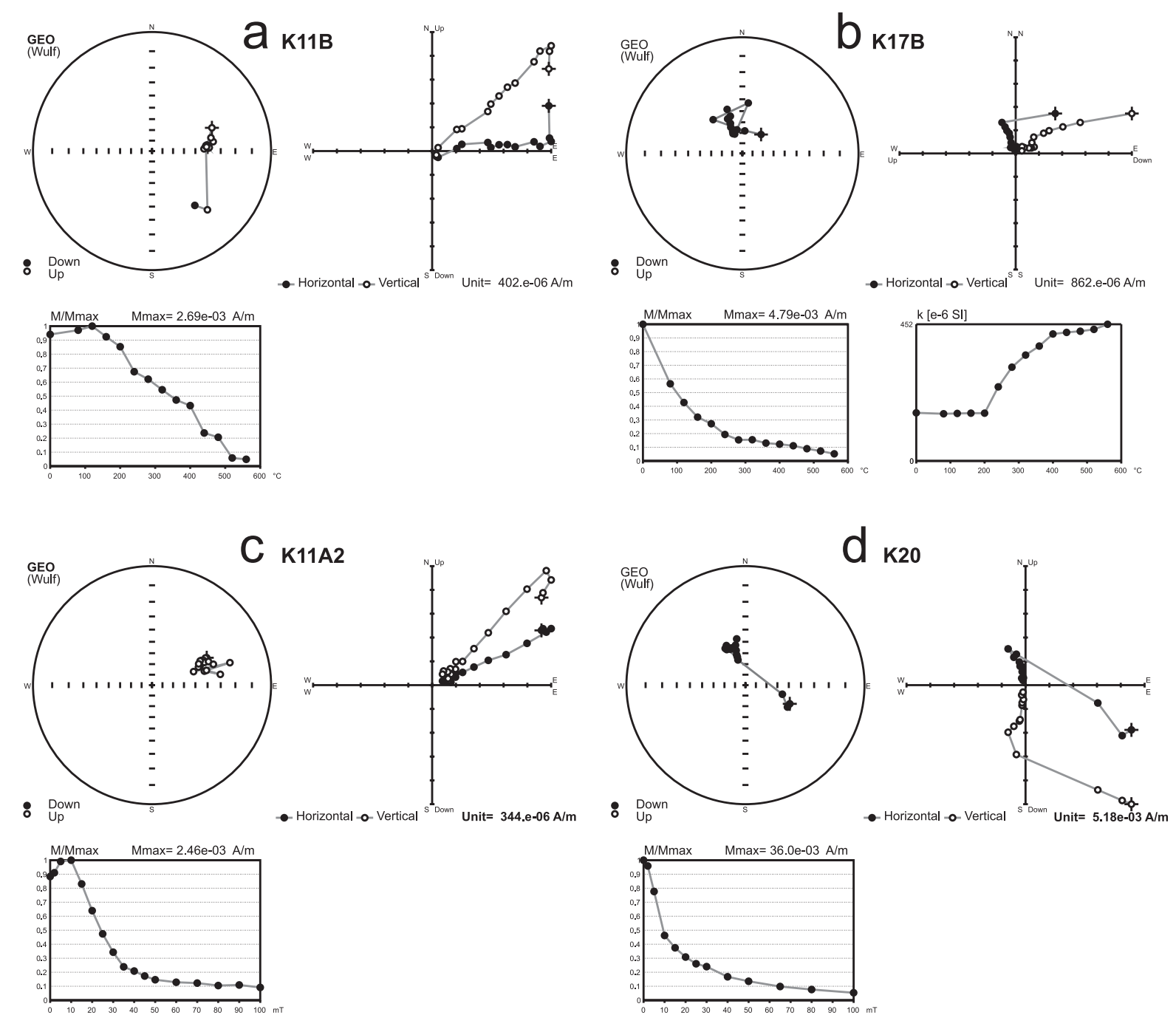

Fig. 5: Results of demagnetization of flowstone samples from Križna jama I profile. Thermal demagnetization: a) K $11 B$ (R polarity); b) K $17 B$ (N polarity), and AF demagnetization: C) K 11A2 (R polarity); D) K 20 (N polarity). A stereographic projection of the NRM of a sample in the natural state (cross-section) and after the progressive TD and/orAF demagnetization. Zijderveld diagram - solid circles represent projection on the horizontal plane (XY), open circles represent projections on the north-south vertical plane (XZ). A graph of normalized values of the remanent magnetic moments versus thermal demagnetizing fields; $M$ - modulus of the remanent magnetic moment of a sample subjected to the TD and/or AF demagnetization. A graph of the normalized values of volume MS versus TD fields; $k$-value of volume MS of a sample subjected to the TD.

and $1.52-1.64 \mathrm{~m}$ were detected in the middle part of the profile (speleothem with bones) and in the basal laminated clays below the principal speleothem layers. All the other samples show $\mathrm{N}$ polarization.

\section{$U$-series dating}

Seven flowstones and stalagmites were sampled for Useries dating in Warsaw (Poland) in spite of the fact that some of samples were macroscopically recrystallized, in places corroded, often with laminas of clay and clay admixture, and sometimes with distinct younger precipitates. We tried to select the cleanest parts of samples, after they were cut for paleomagnetic laboratory samples, which enabled the visual sample control. We partly repeated samples measured by Ford (Ford \& Gospodarič 1989). The reasons were as follows: (1) the pit has changed since December 1982, causing a shift of its wall; (2) some changes in stratigraphy appeared, especially in layers 2 (A) to 4 (B; cf. Fig. 3), and (3) there have been discussions on the age of layer No. 3 of Ford and Gospodarič (1989). Results are given in Tab. 5. 

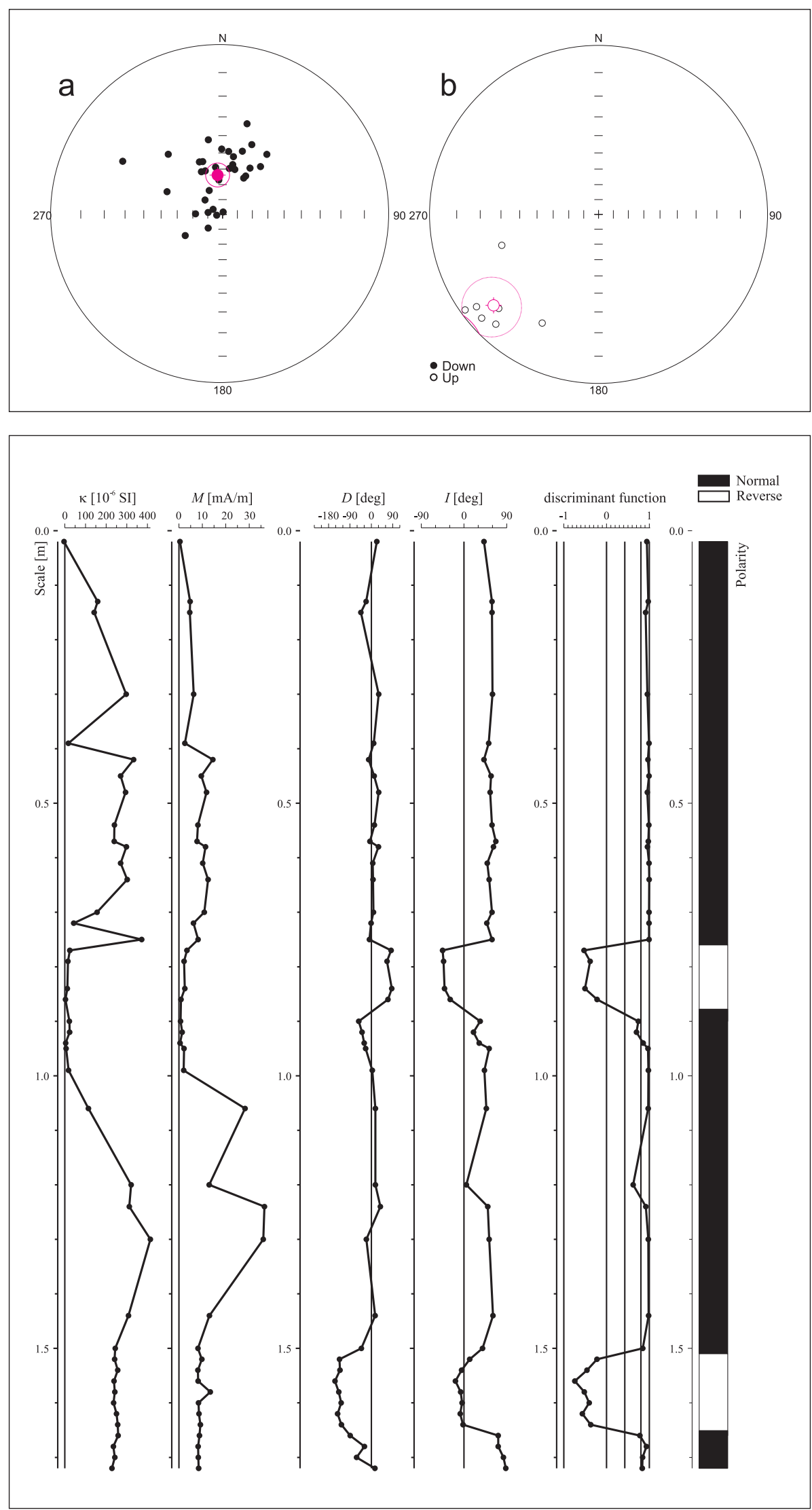

Fig. 6: Directions of C-components of remanence of samples, Križna jama I profile. a) samples with $N$ polarity; $b$ ) samples with $R$ polarity. Stereographic projection, open (full) small circles represent projection onto the lower (upper) hemisphere. The mean direction calculated according to Fisher (1953) is marked by a crossed circle; the confidence circle at the $95 \%$ probability level is circumscribed about the mean direction.

Data of Ford and Gospodarič (1989) are listed in Tab. 6; selected are data only with ${ }^{230} \mathrm{Th} /{ }^{234} \mathrm{U}$ ratio above 20 , i.e. those without principal detrital thorium contamination.

\section{KRIŽNA JAMA II}

Profile Križna jama II was located on the southern side of the same chamber as the Križna jama I profile (Fig. 2). There is a deep depression between the profiles. The top of the profile is situated directly below cave ceiling; the rest was in the steep side of the depression. The profile was briefly described by Brodar and Gospodarič (1973, p. 36).

\section{Lithology}

The profile consisted of two parts. The upper one was situated directly below the cave ceiling, beginning some $18 \mathrm{~cm}$ below an overhanging wall. The lower part of the

Fig. 7: Basic magnetic and paleomagnetic properties, Križna jama I profile. 
Tab. 6: Th/U dating results using $\alpha$-spectrometry from speleothems, Križna jama I profile (selection from Ford \& Gospodarič 1989 according to stratigraphic order).

\begin{tabular}{|c|c|c|c|c|c|c|}
\hline $\begin{array}{l}\text { Sample } \\
\text { No. }\end{array}$ & $\begin{array}{l}\text { U cont. } \\
\text { [ppm] }\end{array}$ & ${ }^{234} U /{ }^{238} U$ & ${ }^{230} \mathrm{Th} /{ }^{234} \mathrm{U}$ & ${ }^{230} \mathrm{Th} /{ }^{332} \mathrm{Th}$ & $\begin{array}{l}\text { Age } \\
\text { [ka] }\end{array}$ & $\begin{array}{l}\text { Layer }^{*} \\
\text { No. }\end{array}$ \\
\hline $\begin{array}{l}\text { YUGK4 } \\
\text { Top }\end{array}$ & 0.15 & 0.925 & 0.728 & 122 & $146_{-31}^{+44}$ & $4(B)$ \\
\hline YUGK1A & 0.11 & 1.089 & 0.763 & 31.4 & $151_{-15}^{+16}$ & $4(B)$ \\
\hline $\begin{array}{l}\text { YUGKK4 } \\
\text { Middle }\end{array}$ & 0.10 & 1.133 & 0.816 & 36.1 & $173_{-22}^{+28}$ & $4(B)$ \\
\hline $\begin{array}{l}\text { YUGK2R } \\
\text { Top }\end{array}$ & 0.12 & 1.189 & 0.703 & 37.4 & $126_{-10}^{+11}$ & $2(A)$ \\
\hline $\begin{array}{l}\text { YUGK2R } \\
\text { Middle }\end{array}$ & 0.11 & 1.232 & 0.725 & 42.7 & $132_{-12}^{+13}$ & $2(A)$ \\
\hline $\begin{array}{l}\text { YUGK2 } \\
\text { Base }\end{array}$ & 0.13 & 1.148 & 0.756 & 29.3 & $146_{-13}^{+14}$ & $2(A)$ \\
\hline
\end{tabular}

${ }^{\star}$ See Figure 3a.
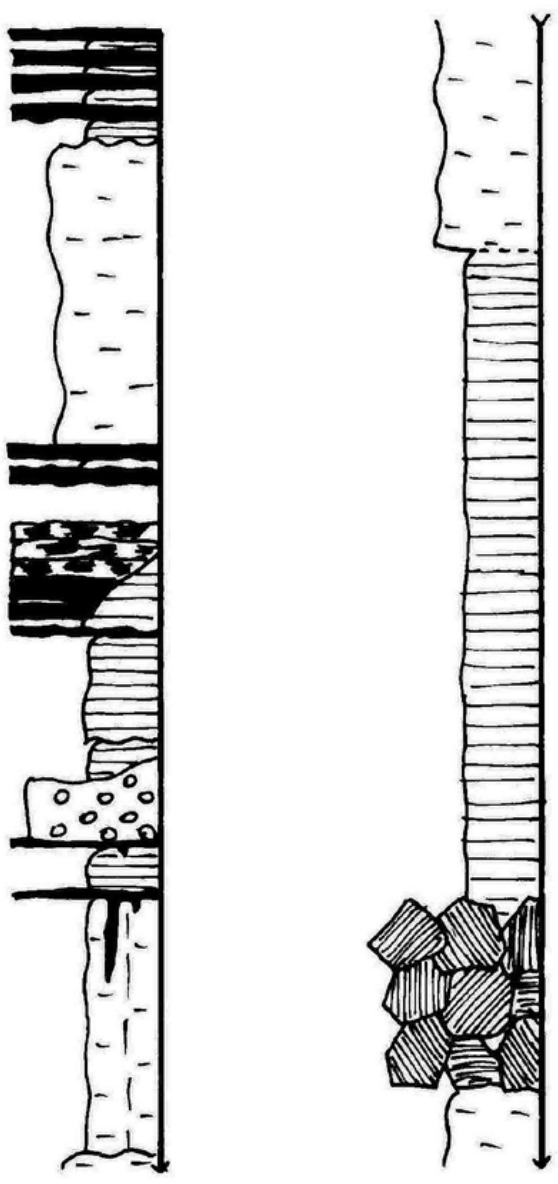

profile started on the edge of platform (an excavated paleontological site) on the side of the deep depression. The lithology of the Križna jama II profile is presented in Fig. 8.

The upper part of the profile (top $80 \mathrm{~cm}$; Figs. 8, 9 $\& 10)$ consisted of an alternation of flowstone layers and silts to clays. The flowstones were mostly laminated and intercalated by brown silt and clay laminas. The basal layer was brown and spongelike, highly porous to vuggy. Silts to clays were finely laminated light grey and yellowish brown to brown and with fine-grained sandy admixture and small limestone clasts in places.

The middle part of the profile $(270 \mathrm{~cm}$; Fig. 8 and partly also 9) was composed of yellowish brown to light brown clays and silty clays, with some layers of clayey silts. In places, sediments were laminated with finegrained sandy admixture, with thin laminas of flowstones, with small clay lithoclasts $(2-3 \mathrm{~cm}$ in size), and with small fenestral structures along the lamination. Columnar disintegration was developed in two horizons.

Fig. 8: Križna jama II profile. Legend: bar - $1 \mathrm{~m}$; black - massive, laminated flowstone; interrupted black - sponge-like flowstone; dotted - sand/sandstone; shaded in different directions - collapsed limestone blocks; horizontal lines - clays; short lines - silt; vertical + horizontal lines - columnar clay; circles - microconglomerate. 


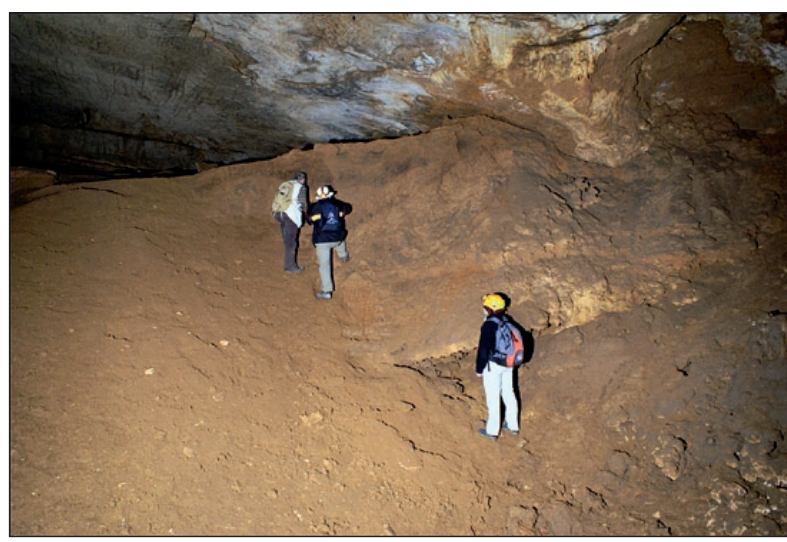

Fig. 9: Upper and middle part of Križna jama II profile in Medvedji rov (Photo: $A$. Mihevc).

Fissures among the polygonal columns were coated by a dark grey to dark greyish violet film (Mn compounds?) and deeply infiltrated by calcite along fissures in the upper columnar layer. Thin calcite crusts and desiccation cracks marked the layer boundaries. About $5 \mathrm{~cm}$ below the top of this middle sequence, a lenticular layer of micro-conglomerate to breccia occurred $(8 \mathrm{~cm})$. It was composed of sub-angular to sub-oval clasts of compact clays derived from the underlying layer, with a light brown silty matrix and calcite-covered erosion base. The silty clayey sequence was underlain by a $25 \mathrm{~cm}$ thick bed of blocky scree composed of angular limestone blocks with yellow clayey matrix and $60 \mathrm{~cm}$ thick layer of light brown silt to clay.

Tab. 7: Mean value and standard deviation of natural remanent magnetization and volume magnetic susceptibility.

\begin{tabular}{|c|c|c|c|}
\hline Križna jama II & $\begin{array}{c}J_{n} \\
{\left[m A \cdot m^{-1}\right]}\end{array}$ & $\begin{array}{c}k^{k n} \times 10^{-6} \\
{[S I]}\end{array}$ & $\begin{array}{c}\text { Interval } \\
{[\mathrm{m}]^{*}}\end{array}$ \\
\hline Mean value & 8.930 & 172.0 & \multirow{3}{*}{$0.14-0.80$} \\
\hline Standard deviation & 2.604 & 95.4 & \\
\hline Number of samples & 21 & 21 & \\
\hline Mean value & 16.775 & 290.4 & \multirow{3}{*}{$0.82-0.91$} \\
\hline Standard deviation & 8.902 & 39.4 & \\
\hline Number of samples & 5 & 5 & \\
\hline Mean value & 13.812 & 262.08 & \multirow{3}{*}{$1.09-2.22$} \\
\hline Standard deviation & 7.824 & 55.7 & \\
\hline Number of samples & 38 & 38 & \\
\hline Mean value & 7.331 & 190.6 & \multirow{3}{*}{$2.245-3.02$} \\
\hline Standard deviation & 2.784 & 19.1 & \\
\hline Number of samples & 25 & 25 & \\
\hline Mean value & 18.132 & 289.9 & \multirow{3}{*}{$3.04-3.715$} \\
\hline Standard deviation & 3.441 & 28.2 & \\
\hline Number of samples & 21 & 21 & \\
\hline
\end{tabular}

* from top to base.

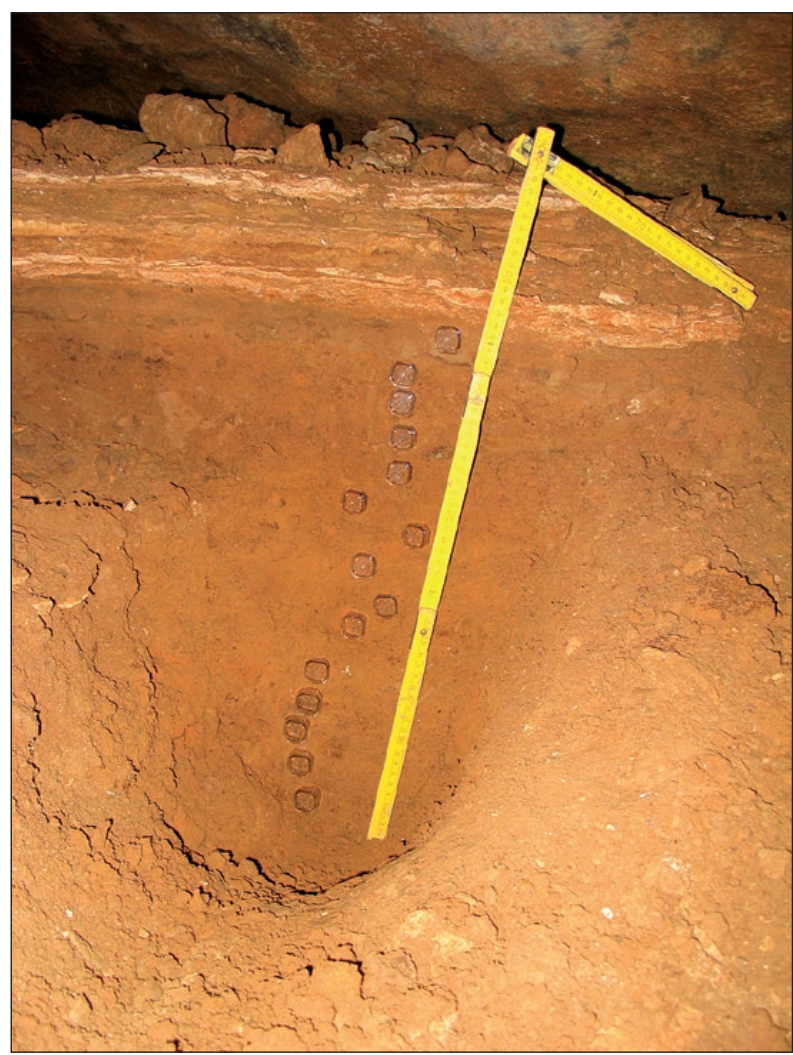

Fig. 10: Upper part of Križna jama II profile in Medvedji rov (Photo: N. Zupan Hajna).

The lower sequence ( $100 \mathrm{~cm}$; Fig. 8$)$ is mostly sandy and represents an upward-fining fluvial cycle. At the top it is limited by three $\mathrm{cm}$ of flowstone. Orange to yellowish brown silt to clay continues down. It is slightly sandy in the lower half, with numerous small decomposed (pulverized) limestone clasts (up to $5 \mathrm{~mm}$ in size) in the upper half and just above the base. Sands below were mediumgrained, clayey, light brown, with abundant small clasts of fresh and decomposed limestone and brownish red $\mathrm{Fe}$ concretions (pellets 1-2 mm in size), with contact clayey cement, with small rounded clayey pellets (about $2 \mathrm{~mm}$ in size), locally cemented up to sandstone grade by crystalline carbonate, in the upper half with distinct lenticular and cross-bedding. Cemen- 

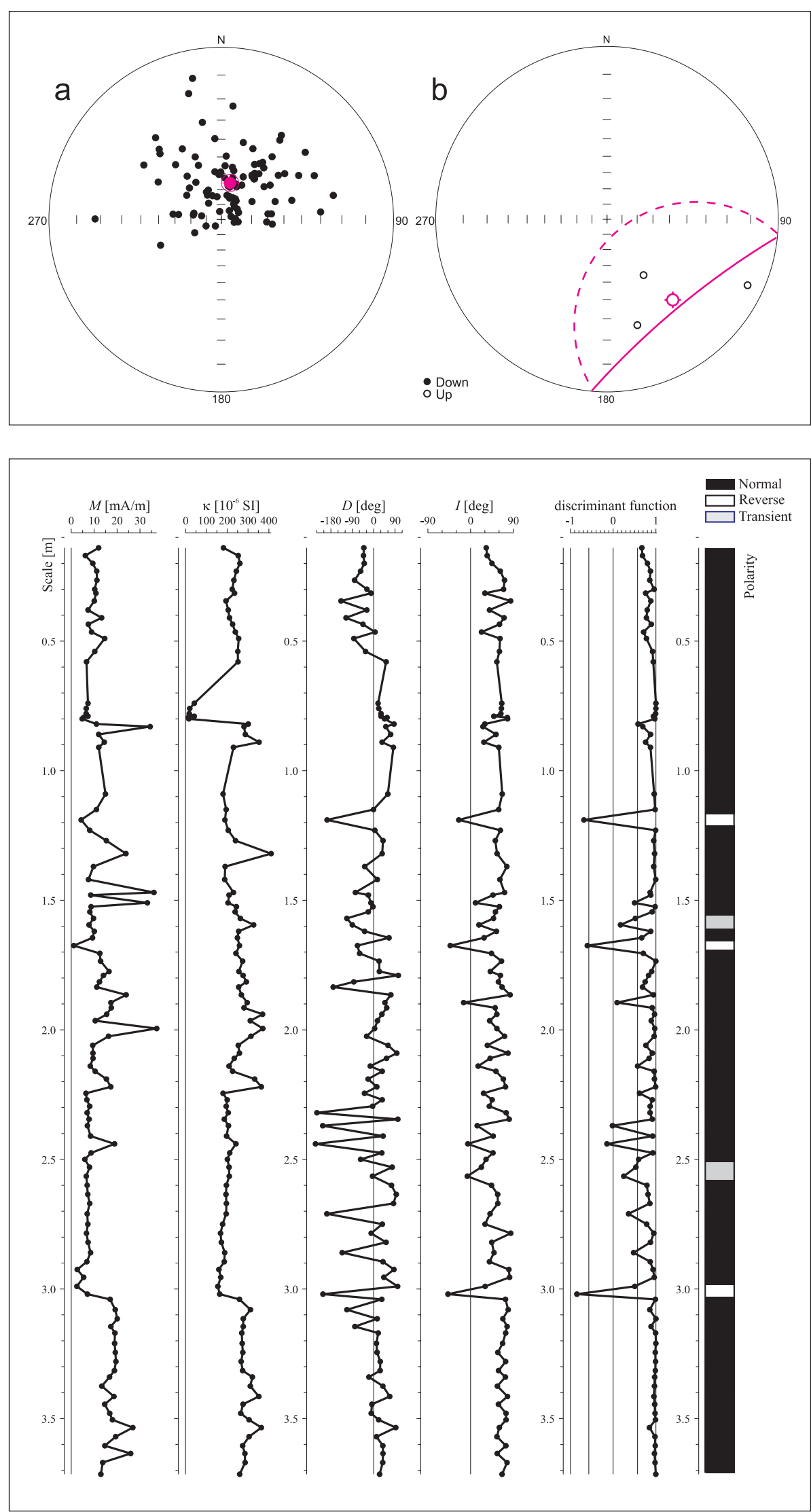

Fig. 11: Directions of C-components of remanence of samples, Križna jama II profile. a) samples with $N$ polarity; b) samples with $R$ polarity. For explanations see Fig. 6.

tation by calcite in the form of irregularly shaped rounded concretions was a typical feature of the whole lower sequence.

\section{Mineralogy}

Quartz and calcite prevailed in the brown-yellow sandy sediment on the top of the profile. Muscovite, chlorite, and montmorillonite were also present and feldspar was detected in traces. Pohar et al. (2002) studied sediments by $\mathrm{X}$-ray analysis from Kittlovo brezno. They detected calcite, hydroxyl-carbonate apatite, fluorapatite, quartz, illite/ muscovite, chlorite and clay fractions containing mixed layered illite/montmorillonite and chlorite/montmorillonite.

\section{Paleomagnetic results} A total of 110 oriented laboratory samples were studied for their paleomagnetic properties. Studied sediments are characterized by a not too high scatter of the NRM intensities $\left(1.2-37 \mathrm{~mA} \cdot \mathrm{m}^{-1}\right)$ and MS values $\left(12-411 \times 10^{-6} \mathrm{SI}\right.$ units). The samples are characterized by low up to intermediate $J_{\mathrm{n}}$ and $k_{\mathrm{n}}$ magnetic

Fig. 12: Basic magnetic and paleomagnetic properties, Križna jama II profile. 
Tab. 8: Mean paleomagnetic directions, Križna jama II.

\begin{tabular}{|c|c|c|c|c|c|c|}
\hline \multirow[t]{4}{*}{$\begin{array}{l}\text { Križna } \\
\text { jama II }\end{array}$} & \multirow[t]{2}{*}{ Polarity } & \multicolumn{2}{|c|}{$\begin{array}{c}\text { Mean paleomagnetic } \\
\text { directions }\end{array}$} & \multirow{2}{*}{$\begin{array}{c}a_{95} \\
\left.{ }^{\circ}\right]\end{array}$} & \multirow[t]{2}{*}{$k$} & \multirow[t]{2}{*}{$n$} \\
\hline & & $D\left[{ }^{\circ}\right]$ & $I[0]$ & & & \\
\hline & $\mathrm{N}$ & 13.44 & 65.33 & 5.07 & 7.79 & 98 \\
\hline & $\mathrm{R}$ & 141.58 & -27.67 & - & - & 3 \\
\hline
\end{tabular}

For explanations see Tab. 3 .

values. Mean $J_{\mathrm{n}}$ and $k_{\mathrm{n}}$ moduli values are documented in Tab. 7. According to both values, the profile may be divided into five parts and categories.

All collected samples were subjected to detailed AF demagnetization in 14 steps in 12-14 fields. Multicomponent analysis was applied to separate the respective RM components for each sample. Three components were isolated after the AF demagnetization. The A-component is undoubtedly of viscous origin and can be demagnetized in the AF (0-2 up to $5 \mathrm{mT})$. The $B-L F C$ is secondary and can be demagnetized in the AF (5-10 up to $15 \mathrm{mT}$ ). The characteristic $C-H F C$ is stable and can be demagnetized or isolated in the AF (ca. 15-80 up to $100 \mathrm{mT}$ ).
The mean direction and associated dispersion parameters of the C-components were calculated using Fisher statistics (Fisher 1953) and are shown in Fig. 11 and Tab. 8 along with their associated circles of $95 \%$ confidence. The mean paleomagnetic directions of the $\mathrm{N}$ polarity of $\mathrm{C}$-components for this profile are $\mathrm{D}=13^{\circ}, \mathrm{I}=65^{\circ}$; and of $\mathrm{R}$ polarity of $\mathrm{C}$-components (for three samples only) are $\mathrm{D}=142^{\circ}, \mathrm{I}=-28^{\circ}$. Two transient zones in $1.56-1.60 \mathrm{~m}$ and $2.55-2.61 \mathrm{~m}$ detected in the middle part of the profile were correlated with shallow paleomagnetic inclination $\left(\mathrm{I}=-7^{\circ}\right)$ and/or anomalous values of declination $\left(\mathrm{D}=247^{\circ}\right)$. Three short $\mathrm{R}$ polarity magnetozones (excursions; at 1.19, 1.675 and $3.02 \mathrm{~m}$ ) are indicated by low values of the NRM intensities (1.2-4.3 mA.m $\left.{ }^{-1}\right)$. All reversal excursions reported in the existing literature correlate with relative minimum intensities. All other samples show N polarity (Fig. 12).

\section{PALEONTOLOGY}

Križna jama is a typical "bear cave" (Hochstetter 1882a, b; Soergel 1940; Cramer 1941), where $99 \%$ of fossil remains are from cave bears (Rakovec 1957; Fig. 13). Hochstetter (1880, p. 539) recorded all age classes of individuals including the embryonal one for Hochstetter's Schatzkammer. Later he (Hochstetter 1882a, p. 304) mentioned all age classes of cave bear except the embryonal one for this area. He recorded the embryonal finds only for Kittl's Bärenhöhle (Hochstetter 1882a, p. 307). Hochstetter $(1882 \mathrm{a}, \mathrm{b})$ accents that there are no traces of transport on the bones and that it seems that they are mostly in situ (see also Bohinec 1963) The cave bear material from Hochstetter's excavations (together with collections of $\mathrm{E}$. Kittl and probably also of Paul Stöger from this locality) is deposited in the Naturhistoriches Museum Wien (Vienna, Austria; U. Göhlich, pers. comm. 2010).

Concerning non-ursid material, Hochstetter (1882a) lists: Gulo borealis (G. spelaeus in 1879a, 1880; G. borealis in 1881b): left mandible and left ulna (without ulna in 1880); marten species similar to Martes foina (as Mustela in Hochstetter): skull, hemimandible and right humerus (without humerus in 1880); and Canis lupus: 2 cervical vertebrae (only 1 in 1879a). Liebe (1879) revised part of this material (ulna of glutton, skull of marten and vertebrae of wolf). It could be mentioned that he redetermined the marten species as M. abietium (= M. martes) and the wolf as C. spelaeus (he specified that the verte-

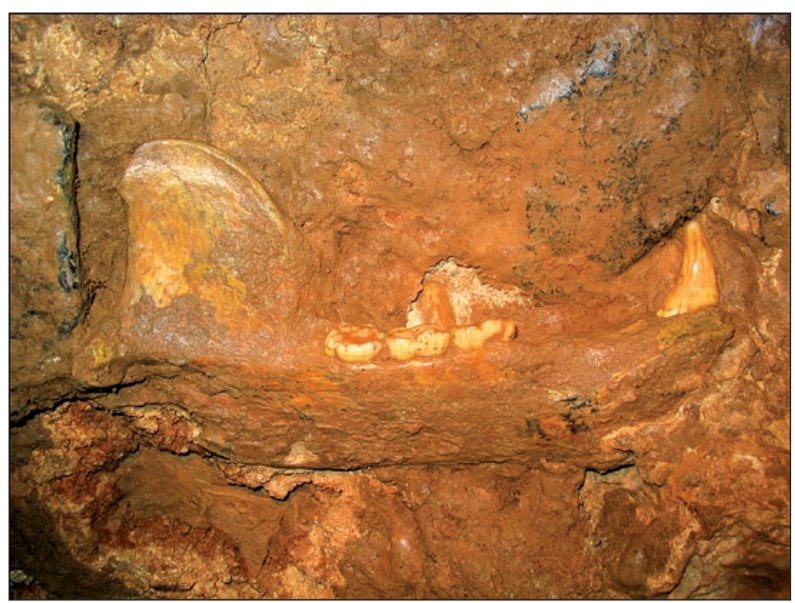

Fig. 13: Cave bear mandible cemented below the speleothem in Medvedji rov, Križna jama (Photo: N. Zupan Hajna).

brae material consists of epistopheus fused together with the next vertebra). Moreover, Döppes (2001, p. 44) listed also Ursus arctos, Panthera spelaea, and Crocuta spelaea 
(contrary to Hochstetter 1882a). Döppes (2000, 2001) discussed remains of Gulo gulo from this locality.

All the fauna was traditionally dated to the Last Glaciation (=Weichselian; e.g. Gospodarič 1973, 1974, 1987; Rakovec 1975). Based on numerical dating, Gospodarič (1988) attributed Riss (=Saalian) and Riss/Würmian (=Eemian) ages to flowstones, but he supposed Würmian1 and Würmian1/2 (=Weichselian) ages for the majority of cave bear bones.

Revision excavations in 1999 and 2001 were carried out with respect to the taxonomy of cave bears in both principal sites (Kittlovo brezno and Medvedji rov) within the cave (Rabeder \& Withalm 2001; Pohar et al. 2002). Based on its large size (mentioned already by Hoschstetter 1882a), highly evolved dentition (especially p4, P4), and the mtDNA haplotype (Rabeder \& Hofreiter 2004; Withalm 2004; Hofreiter 2005; Rabeder et al. 2008), the cave bears from Križna jama are designated to the most evolved representatives of the spelaeus-lineage, similar to those from Potočka Zijalka (Eastern Alps, Slovenia) or Gamssulzenhöhle (Totes Gebirge, Northern Calcareous Alps, Austria), and determined as Ursus ingressus (see Rabeder et al. 2004 for cave bear taxonomy and Rabeder 1983, 1989, and 1999 for the significance of dental morphology). The bear remains from both Medvedji rov (3 specimens) and Kittlovo brezno (2 specimens) were also dated by the radiocarbon method with results between ca. 47-45 ka and 45-32 ka, respectively (Rabeder \& Withalm 2001; Döppes 2001; Pohar et al. 2002; Rabeder 2009), that correspond well with the supposed occurrence of $U$. ingressus in this area (see e.g. Rabeder \& Hofreiter 2004; Rabeder 2007, 2010; Pohar \& Rabeder 2010). The pre-Weichselian population of cave bear in this region (Vindija Cave, Croatia) is characterized by smaller size and a higher percentage of more archaic morphotypes of check teeth (Paunović 1988, 1991) than we find in $U$. ingressus.

\section{DISCUSSION}

The correlation between the Križna jama II and Križna jama I profiles is based on similar lithology and paleomagnetic properties. The upper part, an alternation of speleothems and silts to clays in Križna jama II (base at $0.8 \mathrm{~m}$ ), is undoubtedly equivalent to layers No. 1 to 14 in Križna jama I (base at $1.5 \mathrm{~m}$ ). Layer No. 15 (Križna jama I; clays with columnar disintegration) can be compared with the similar layer in Križna jama II (below $1.14 \mathrm{~m}$ ). This is supported by the detected short R polarized zone in both profiles in equivalent positions. The lithological correlation indicates that about $40 \mathrm{~cm}$ of sediments from the top of the middle sequence of Križna jama II profile are missing in the Križna jama I site.

Mineralogy of cave sediments performed by Brodar and Gospodarič (1973), Pohar et al. (2002) and Zupan Hajna et al. (2008b) indicates similarity with sediments in caves of the region ( $c f$. Zupan Hajna et al. 2008b), perhaps derived from more weathered sources. The quartz grains were interpreted as clastic (fluvial or eolian) re-deposited in the cave during the Pleistocene (e.g. Brodar \& Gospodarič 1973). Pebbles of oolitic bauxite were derived from the surface above Križna jama where they were formed. An origin and re-deposition from the Triassic bauxite was excluded. Bauxites can be linked (see Bosák et al. 1999) with surface paludal deposits, which underwent at least the initial stage of bauxitization. Limonite ooids and hematite grains are derived most probably from terra rossa-type soils eroded from the surface above and from the vicinity of the cave.

\section{KRIŽNA JAMA I}

Ford and Gospodarič (1989) stated that flowstone below the second horizon with Ursus gr. spelaeus is older than $146 \mathrm{ka}$, and the flowstone layer above it was deposited between 146 and $126 \mathrm{ka}$. The bear bone-bearing layer is therefore the result of a single-flood episode; the upper layer with Ursus gr. spelaeus is younger but contains redeposited bones from the lower layer. Three bone samples from the upper layer, above flowstones (i.e. above layer No. 4 of Ford \& Gospodarič 1989; cf. Pohar et al. 2002, p. 50), were dated by the radiocarbon method by Rabeder and Withalm (2001) from $44.8+1.8 /-1.4$ to 46.7 $+2.4 /-1.8 \mathrm{ka}$ BP (data were re-published also by Pohar et al. 2002 and others), correcting the age of about $38 \mathrm{ka}$ expected by Ford and Gospodarič (1989). Such old (40 ka and older) radiocarbon dates (as presented by Rabeder \& Withalm 2001) can be doubtful; they might as well be so close to the detection limit that they are practically infinite, Other authors do not mention if radiocarbon dates represent ${ }^{14} \mathrm{C}$ years or calendar (corrected) ages.

Comparison of our profile (Fig. 3b) with that of Ford and Gospodarič (Fig. 3a) indicated only a slightly different lithostratigraphy. The upper parts are nearly identical (for correlation see Tab. 1). The middle parts 
slightly differ: the layer with our sample No. K09 is equivalent to layer 4 or B, our layers 8 and 10 are equivalent to layer No. 3, and our layers 11 to 12 are equivalent to layer 2 or B of Ford and Gospodarič (1989). Nevertheless we detected a further layer No. 9/2 (flowstone with cave bear bones; paleomagnetic sample $\mathrm{K} 11$ ), which is not marked within layer No. 3 of Ford and Gospodarič (1989). Also the lower part is lithologically more complicated than was simply drawn by Ford and Gospodaric (1989), i.e. alternation of flowstone, silts and carbonatecemented silts. Cave bear bones occurred in our layers 5 to 10 (Fig. 3b).

New radiometric dates proved the results of Ford and Gospodarič (1989). The best analysis was obtained from sample No. K 45, the top of a thick columnar stalagmite growing from layer No. $9 / 1$, i.e. $93.8+8.3 /-7.8$ $\mathrm{ka}$ (Tab. 5). The growth ceased just before the start of the last glacial. The upper flowstone layer (our No. 9/1) is dated to $137+22 /-19$ ka (sample K 41 middle; Tab. 5). Dating of sample K 41 lower part (Lab. No. W 1616; Tab. 5) is inconsistent with other results. The sample was collected in the weathered part of the flowstone. Dating of such samples has a high risk of secondary precipitation of younger calcite in pores. The final obtained age is younger, depending on the mixture proportions of the dated calcite and younger calcite fillings of secondary pores. The problematic sample has different uranium content and isotopic composition as compared with other samples, which suggest that young secondary calcite is characterized by high $U$ concentration and strong ${ }^{234} \mathrm{U}$ depletion. This process is a kind of "open system" as a supply of highly depleted uranium in ${ }^{234} \mathrm{U}$. The middle flowstone layer (No. 9/2) shows a Th/U date of $118+39 /-31 \mathrm{ka}$ (Tab. 5). Analyses of samples K 41 middle and $\mathrm{K} 46$ also contained some detrital thorium contamination (the ${ }^{230} \mathrm{Th} /{ }^{232} \mathrm{Th}$ ratio was close to 20 with wide error bars; Tab. 5); nevertheless error bars of both analyses overlap. Part of the new dates agreed with the results of Ford and Gospodarič (1989) analyses: upper flowstone layers give older ages than lower ones, but error bars partly overlap. This result can probably reflect the irregularity in recrystallization combined with high detrital thorium admixture (Tab. 5), that can explain high ages obtained for some flowstone samples ( $c f$. Ortega et al. 2005; Ford \& Williams 2007) and from that can explain the seeming violation of the superposition law. Stalagmites occurring in layer No. 11 (No. 2 /A/ of Ford \& Gospodaric 1989; Fig. 3A) indicate that the precipitation of the layer could not have been sheltered by the seemingly older layer No. 9/1, proving that the profile deposited in normal stratigraphic order.

Remains of cave bears in Layers No. 4 (B) to 2 (B) of Ford and Gospodarič (1989) are definitely older than
$93.8+8.3 /-7.8$ ka. Radiocarbon dates of ca. 47 to $45 \mathrm{ka}$ by Rabeder and Withalm (2001) from cave bear bones found above Layer No. 4 (B) exclude bone re-deposition from the lower layer as speculated by Ford and Gospodarič (1989). The preservation of fossil bones with no traces of transport also indicates their in situ position (Hochstetter 1882a, b; Bohinec 1963), and therefore the sandwiching of younger fill between flowstones (Layers No. 4 and 2) is improbable.

Prevailing $\mathrm{N}$ polarization of the whole profile indicates age younger than the Brunhes/Matuyama boundary at $780 \mathrm{ka}$. Reverse paleomagnetic polarity in layer No. 9/2 (paleomagnetic sample K 11, Th/U sample No. $\mathrm{K} 46)$ may indicate Blake excursion in normal polarized Brunhes Chron (117.1 \pm 1.2 to $111.8 \pm 1.0$ ka BP; Lovlie 1989; Smith \& Foster 1969; Zhu et al. 1994), labeling more precisely the age of the upper part of layer No. 9/2. The short R polarized magnetozone below speleothems (samples K 24 to K 30) represents one of the short-lived excursions of the magnetic field within the Brunhes Chron. It is older than about 190/201 ka, as indicated from error bars of Th/ $\mathrm{U}$ dates (Tab. 6); most probably Jamaica-Pringle Falls (210 $\pm 5 \mathrm{ka})$, Namaku (230 $\pm 12 \mathrm{ka})$ or Calabrian Ridge ( $255 \pm 5$ ka; Bleil \& Gard 1989; Herrero-Bervera et al. 1989, 1994; Langereis et al. 1997; McWilliams 2001; Nowaczyk et al. 1994; Ryan 1972; Shane et al. 1994; Smith \& Foster 1969; Tanaka et al. 1996). This excursion can be correlated with the upper excursion in the Križna jama II profile. The correlation indicates that some ca. $40 \mathrm{~cm}$ of sediments are missing in the Križna jama I profile under flowstones.

Remains of small snails reported by Brodar and Gospodarič (1973) from layer No. 1 of Ford and Gospodarič (1989) were not found by us. Stable isotopes from snails studied by Gospodarič (1988) indicated climatic conditions similar to the present. Therefore he expected that the sediment is of Mindel/Riss (= Holsteinian; MIS 11) age. Our data indicate that the sediment belongs to some of warmer periods of Saalian glacial (perhaps MIS 7). The profile deposited during alternation of subaerial periods (erosion, flowstone deposition, hibernation of cave bears) with intensive floods, which could be the cause of massive exitus of cave bears.

Deposition in the Križna jama I profile can be dated to the Last Glacial (Weichselian), Eemian interglacial (MIS 5) and upper part of Saalian glacial (perhaps MIS 6 to 7$)$.

\section{KRIŽNA JAMA II}

The sediments were deposited in a cave fluvial environment. The upper $80 \mathrm{~cm}$ are of the same origin as the Križna jama I profile. The middle part below flowstones 
(up to $3.5 \mathrm{~m}$ ) resulted from slack water deposition in the still environment of cave lakes, alluvial flats and crevasse splays. The bedding plane at $1.14 \mathrm{~m}$ represents an important hiatus in the deposition, which can hide substantial time, which is expressed in carbonate infill of columnar disintegration of the underlying layer (up to $1.48 \mathrm{~m}$ ). The layer of coarse-grained angular scree between 2.65 and $2.9 \mathrm{~m}$ represents, most probably, the result of seismic-derived collapse. The clay matrix was washed to interstices during the deposition of overburden. The sequence below it represents a fluvial deposit. Carbonate cementation in the lower part of the profile (below $3.53 \mathrm{~m}$ ) probably indicates warmer climatic conditions.

According to the paleomagnetic results (prevailing $\mathrm{N}$ polarization) and parameters we assume that deposition took place within the Brunhes Chron $(<780 \mathrm{ka})$. Three short $\mathrm{R}$ polarized magnetozones represent shortlived excursions within the Brunhes Chron. They are older than ca 190/201 ka, which results from lithologi- cal correlation with the profile I. The upper excursion is identical with the lower one in Križna jama profile I; the lower two ones are older, i.e. Portuguese margin (ca $290 \mathrm{ka}$ ) or Calabrian Ridge 1 (ca 315 or $335 \mathrm{ka}$; Langereis et al.1997; Thouveny et al. 2004). The upper excursion terminates on hiatus horizon and is determined only on one sample (ca. $4 \mathrm{~cm})$, in comparison with Križna profile I where 7 samples have $\mathrm{R}$ polarity and a thickness of 12 $\mathrm{cm}$. The preservation of very narrow magnetozones with different polarization than the surroundings is not often reported from cave sediments. Nevertheless, our team also detected them in lutitic sediments in some other caves in Slovakia (Bella et al. 2007) and Slovenia (Zupan Hajna et al. 2008a, b).

Deposition in the Križna jama profile II can be dated to the Last Glacial (Weichselian), Eemian interglacial (MIS 5), Saalian glacial (MIS 6 to 10) and Holsteinian interglacial (MIS 11).

\section{CONCLUSIONS}

Profiles Križna jama I and II represent remains of fill of the Medvedji rov. Sediments originally filled the whole passage, probably up to the cave roof, at least in some passage sections. The Križna jama I profile can be correlated with the upper part of the Križna jama II profile, but with less preserved stratigraphic sequence. The upper part consists of alternation of speleothem layers (flowstone sheets with small stalagmites, sometimes with bones of Ursus gr. spelaeus) and fine-grained siliciclastics (loams, clays, silts), often with bones of cave bear. It resulted from alternation of subaerial periods and floods. The middle fine-grained section resulted from calm deposition in the unagitated environment of cave lakes, alluvial flats and crevasse splays. The sandy sequence at the profile base is fluvial deposit. Carbonate cementations in the lower part of the profile distinctly indicate warmer climatic conditions.

Radiocarbon and U-series dates clearly indicate two different ages of cave bear thanatocenoses. Those above the flowstone crust numbered 4 (B) by Ford and Gospodarič (1989) were dated to ca. 47-45 ka by Rabeder and Withalm (2001); those included in Layers 4 (B), 3 and 2 (A; our layers $9 / 1,8.9 / 2,10$ and 11 ) are older than ca. $94 \mathrm{ka}$. The detailed internal lithology reflected in the alternation of our layers 10 to $9 / 1$ and their low thicknesses exclude expected sandwiching of younger layers into eroded/washed spaces among flowstone crusts Nos. 11, 10, 9/2 and 9/1 expected by Ford and Gospodaric
(1989); more crusts also contain bear bones cemented in situ. Rabeder and Withalm's (2001) radiocarbon dates and state of bone preservation (Hochstetter 1882a; Bohinec 1963) exclude Ford and Gospodaričs (1989) model on re-deposition of bear bones from older assemblage to sediments above flowstone crusts. U-series and isotopic data nevertheless indicate some post-depositional changes in calcitic flowstones, which make the record poorly readable.

According to the paleomagnetic results (prevailing $\mathrm{N}$ polarization) and parameters we assume that deposition took place within the Brunhes Chron $(<780 \mathrm{ka})$. There were discovered in total four short-lived $\mathrm{R}$ excursions of the magnetic field. The upper one (profile I) might be correlated with the Blake excursion according to U-series dating of layer No. 9/2. The lower ones have to be older than ca. 190/201 ka (error bars of U-series dates of Ford \& Gospodarič 1989). If calcite-cemented fluvial sandstones represent deposition in Cromerian interglacial, the lower three $\mathrm{R}$ polarity excursions can be correlated with some of Jamaica-Pringle Falls, Namaku, Calabrian Ridge, Portuguese margin or Calabrian Ridge 1 excursions (210-335 ka).

Deposits in studied profiles in Križna jama were deposited during the Last Glacial (Weichselian), Eemian interglacial, Saalian glacial and Holsteinian interglacial. 


\section{ACKNOWLEDGEMENTS}

We are grateful to Mr. Marko Simić from Agencija RS za okolje (Environmental Agency RS) for issuing permissions for the field work in caves. We acknowledge field assistance of local cavers Mr. Alojz Troha and Mr. Matej Kržič (Društvo ljubiteljev Križne jame) during field work in Križna jama.

Paleomagnetic analyses were performed by Dr. Daniela Venhodová, Mrs. Jana Drahotová, Mgr. Petr Schnabl and Mr. Jiří Petráček. Software for evaluation of paleomagnetic measurements was prepared by Dr. Ota Man. Samples for paleomagnetic analyses were cut by Mr. Jiří Petráček (all from the Laboratory of Paleomagnetism, IG AS CR). Samples for the X-ray analysis and evaluation were prepared by Dr. Roman Skála and Mr. Jiří Dobrovolný (all from the Laboratory of analytical methods, IG AS CR) and by Dr. Meta Dobnikar (Department of Geology, Faculty of Natural and Technical Sciences, Ljubljana University, Slovenia). Drawings were performed by Mr. Jurij Hajna (IZRK ZRC SAZU), Mr. Josef Forman, Dr. Ota Man, Mgr. Petr Schnabl and Mgr. Stanislav Šlechta (IG AS CR).

Travel costs were covered within the frame of the program KONTAKT of the Ministry of Education, Youth and Sports of the Czech Republic and Slovenian Ministry of Science and Technology (later Ministry of Education, Sport and Science) Nos. 28-2003-04 (Reconstruction of speleogenesis and karstogenesis from the study of cave fill,
Slovenia; 2003-2004); 13-2005-06 (Paleomagnetic studies of sediments in karst areas of Slovenia: implication for paleotectonic reconstructions; 2005-2006). Analyses, processing and interpretation in the Czech Republic were carried out within the Programs of Advancements in Scientific Research in Key Directions of the Academy of Sciences of the Czech Republic No. K3046108 (2001-2004), Research Plans of the Institute of Geology AS CR Nos. CEZ A09/98 Z3-013-912 (1999-2004) and AV0Z30130516 (2005-2011), and Grants of the Grant Agency of the Academy of Sciences of the Czech Republic Nos. IAA3013201 (Magnetomineralogical and magnetostratigraphic research of cave and fluvial sediments in the Central European region; 2002-2005), and IAA30013001 (Paleomagnetic research of karst sediments: paleotectonic and geomorphological implications; $2007-$ 2010). Research activities in Slovenia were covered by research programs of the Ministry of Science of Slovenia and Slovenian Research Agency Nos. P6-0119-0618 and P0-0119 (Karst Research), and projects Nos. J6-30350618-01 (Origin and development of karst caves; 20012004) and J6-6345-0618-04 (Development and function of caves in different speleological settings; 2004-2006).

Special thanks to Acta carsologica for permission to reprint some of drawings. We highly acknowledge comments and language corrections by reviewers.

\section{REFERENCES}

Badiura, R., 1909: Križna jama.- Dom in svet, 22, 1, 30 33.

Bavdek, A., Mihevc, A., Toškan, B. \& A. Velušček, 2009: Arheološke najdbe iz Križne jame.- Arheološki vestnik, 60, 17-31.

Bella, P., Bosák, P., Pruner, P., Hochmuth, Z. \& H. Hercman, 2007: Magnetostratigrafia jaskynných sedimentov a speleogenéza Moldavskej jaskyne a spodných častí Jasovskej jaskyne.- Slovenský kras (Acta Carsologica Slovaca), XLV, 15-42..

Bleil, U. \& G. Gard, 1989: Chronology and correlation of Quaternary magnetostratigraphy and nannofossil biostratigraphy in Norwegian-Greenland Sea sediments.- Geologische Rundschau, 78, 1173-1187.

Bohinec, W., 1963: Die Križna Jama (Kreuzberghöhle) bei Lož, Slowenien.- In: $3^{\text {rd }}$ International Congress of Speleology, 2, 211-214, Wien.
Bosák, P., Mihevc, A., Pruner, P., Melka, K., Venhodová, D. \& A. Langrová, 1999: Cave fill in the Črnotiče Quarry, SW Slovenia: Paleomagnetic, mineralogical and geochemical study.- Acta carsologica, 28/2, 2, 15-39.

Brodar M. \& R. Gospodarič, 1973: Medvedji rov v Križni jami in tamkajšnji ostanki jamskega medveda.- In: Mladinski raziskovalni tabori (1971-1972), Republiški koordinacijski odbor gibanja "Znanost mladini", pp.30-46, Ljubljana.

Buser, S., Grad, K. \& M. Pleničar, 1967: Osnovna geološka karta SFRJ, list Postojna, $1: 100$ 000.- Zvezni geološki zavod Beograd, Beograd.

Chadima, M. \& F. Hrouda, 2006: Remasoft 3.0 - a userfriendly paleomagnetic data browser and analyzer.Travaux Geophysiques, 27, 20-21. 
Cramer, H., 1941: Der Lebensraum des eiszeitlichen Höhlenbären und die "Höhlenbärenjagdkultur".Zeitschrift der Deutschen Geologischen Gesellschaft, 93, 392-423.

Döppes, D., 2000: Pleistocene finds of Gulo gulo L. in Austria and Slovenia.- Geološki zbornik, 15, 67-80.

Döppes, D., 2001: Gulo gulo (Mustelidae, Mammalia) im Jungpleistozän Mitteleuropas.- Beiträge zur Paläontologie, 26, 1-95.

Fisher, R., 1953: Dispersion on a sphere.- Proceedings of the Royal Society, A 217, 295-305.

Ford, D.C. \& R. Gospodarič, 1989: U series dating studies of Ursus spelaeus deposits in Križna jama, Slovenia.Acta Carsologica, 18, 39-51.

Ford, D.C. \& P.W. Williams, 2007: Karst Hydrology and Geomorphology.- Wiley, pp. 562, Chichester.

Gorka, P. \& H. Hercman, 2002: URANOTHOR v. 2.5. Delphi Code of calculation program and user guide.Archive, Quaternary Geology Department, Institute of Geological Sciences, Polish Academy of Sciences, Warsaw.

Gospodarič, R., 1974: Fluvialni sedimenti v Križni jami.Acta carsologica, 6, 327-366.

Gospodarič, R., 1987: Geochronology of Quaternary karst processes in the karst of NW Yugoslavia.- In: International Union for Quaternary Research. XII ${ }^{\text {th }}$ International Congress, Programme and Abstracts, 176, Ottawa.

Gospodarič, R., 1988: Paleoclimatic record of cave sediments from Postojna karst.- Annales de la Société géologique de Belgique, 111, 91-95.

Gratzy, O., 1897: Die Höhlen und Grotten in Krain.Mittheilungen des Musealvereines für Krain, 10, 5, 133-174.

Hauer, F.R. v., 1879: Jahresbericht des Directors Hofrath Fr. R. v. Hauer.- Verhandlungen der kaiserlich-königlichen Geologischen Reichsanstalt, Jahrgang 1879, 1, 1-14.

Herrero-Bervera, E., Helsley, C.E., Hammond, S.R. \& L.A. Chitwood, 1989: A possible lacustrine paleomagnetic record of the Blake episode from Pringle Falls, Oregon, U.S.A.- Physics of the Earth and Planetary Interiors, 56, 112-123.

Herrero-Bervera, E. et al., 1994: Age and correlation of a paleomagnetic episode in the western United States by ${ }^{40} \mathrm{Ar} /{ }^{39} \mathrm{Ar}$ dating and tephrochronology: The Jamaica, Blake, or a new polarity epsiode?- Journal of Geophysical Research, 99, 24091-24103.
Hochstetter, F. v., 1879a: Die Ergebnisse der von der Commission im verflossenen Jahre veranlassten Forschungen und Ausgrabungen.- Anzeiger der kaiserlichen Akademie der Wissenschaften, mathematisch-naturwissenschaftliche Classe, 16 (Jahrgang 1879), 2 (Sitzung vom 16. Jänuer 1879), 13-19.

Hochstetter, F. v., 1879b: Die Ergebnisse der von der Commission im vergangenen Jahre veranlassten Forschungen und Ausgrabungen.- Anzeiger der kaiserlichen Akademie der Wissenschaften, mathematisch-naturwissenschaftliche Classe, 16 (Jahrgang 1879), 27 (Sitzung vom 18. December 1879), 295-299.

Hochstetter, F. v., 1880: Ergebnisse der Höhlenforschungen im Jahre 1879.- Sitzungsberichte der kaiserlichen Akademie der Wissenschaften, mathematisch-naturwissenschaftliche Classe, I. Abteilung, 80 (Jahrgang 1879), 5 (XXVII. Sitzung vom 18. Dezember 1879), 526-541.

Hochstetter, F. v., 1881a: Die Kreuzberghöhle bei Laas in Krain.- Denkschriften der Mathematiche-naturwissenschaftliche Klasse der Akadademie der Wissenschaften, 43, 18 pp., Wien (preprint of Hostetter 1882a).

Hochstetter, F., 1881b: Die Kreuzberghöhle bei Laas in Krain und der Höhlenbär.- Anzeiger der kaiserlichen Akademie der Wissenschaften, mathematisch-naturwissenschaftliche Classe, 18 (Jahrgang 1881), 5, 39-40.

Hochstetter, F. v., 1882a: Die Kreuzberghöhle bei Laas in Krain.- Denkschriften der Mathematiche-naturwissenschaftliche Klasse der Akadademie der Wissenschaften, 43, 293-310.

Hochstetter, F. v., 1882b: Die Kreuzberghöhle bei Laas in Krain und der Höhlenbär.- Humboldt. Monatsschrift für die gesamten Naturwissenschaften, 1, April, 127-131.

Hofreiter, M., 2005: Evolutionsgeschichte alpiner Höhlenbären aus molukulargenetischer Sicht.- Mitteilungen der Kommission für Quartärforschung der Österreichischen Akademie der Wissenschafften, 14, 67-72.

Ivanovich, M. \& R.S. Harmon (eds.), 1992: Uranium series disequilibrium. Applications to environmental problems.- Second edition, Clarendon, pp. 910, Oxford.

Jelínek, V., 1966: A high sensitivity spinner magnetometer.- Studia Geophysica et Geodaetica, 10, 58-78.

Jelínek, V., 1973: Precision A.C. bridge set for measuring magnetic susceptibility and its anisotropy.- Studia Geophysica et Geodaetica, 17, 36-48. 
Južnič, S., 2006: Karst research in the $19^{\text {th }}$ Century - Karl Dežman's (1821-1889) work.- Acta carsologica, 35, $1,139-148$.

Kirschvink, J.L., 1980: The least-squares line and plane and the analysis of paleomagnetic data.- Geophysical Journal of the Royal Astronomical Society, 62, 699-718.

Kogovšek, J., Prelovšek, M. \& M. Petrič, 2008: Underground water flow between Bloke plateau and Cerknica polje and hydrologic function of Križna jama, Slovenia. Acta carsologica, 37, 2-3, 213-225.

Langereis, C.G., Dekkers, M.J., de Lange, G.J., Paterne, M. \& P.J.M. Santvoort, 1997: Magnetostratigraphy and astronomical calibration of the last $1.1 \mathrm{Myr}$ from eastern Mediterranean piston core and dating of short events in the Brunhes. - Geophysical Journal International, 129, 75-94.

Liebe, K.T., 1879: Die fossile Fauna der Höhle Výpustek in Mähren nebst Bemerkungen betreffs einiger Knochenreste aus der Kreuzberghöhle in Krain.Sitzungsberichte der kaiserlichen Akademie der Wissenschaften, mathematisch-naturwissenschaftliche Classe, 79, 472-490.

Løvlie, R., 1989: Paleomagnetic excursions during the last interglacial-glacial cycle - A synthesis.- Quaternary International, 3-4, 5-11.

McWilliams, M., 2001: Global correlation of the $223 \mathrm{ka}$ Pringle Falls Event.- International Geological Review, 43, 191-195.

Michler, I., 1934a: Križna jama.- Proteus, Ljubljana, I, 5, 97-102.

Michler, I., 1934b: Nova odkritja v Križni jami.- Proteus, Ljubljana, I, 9, 188-195.

Musil, R., 1980: Ursus spelaeus - der Höhlenbär, I.- Weimarer Monographien zur Ur- und Frühgeschichte, 2, 1-94.

Novak, D., 1966: Poročilo o barvanju v Križni jami 1965.Naše jame, 8, 1-2.

Novak, D., 1969: O barvanju potoka v Križni jami 1965.Geografski vestnik, 41, 75-79.

Nowaczyk, N.R., Antonow, M., Knies, J. \& R.F. Spielhagen, 1994: Magnetostratigraphic data from late Quaternary sediments from the Yermak Plateau, Arctic Ocean: evidence for four geomagnetic polarity events within the last $170 \mathrm{Ka}$ of the Brunhes Chron.- Geophysical Journal International, 117, 453-471.

Ortega, R., Maire, R., Devès G., \& Y. Quinif, 2005: Highresolution mapping of uranium and other trace elements in recrystallized aragonite calcite speleothems from caves in the Pyrenees (France): Implication for U-series dating.- Earth and Planetary Science Letters, 237, 3-4, 911-923.
Paunović, M., 1988: Morphometrische und morphogenetische Untersuchungen der Ursidenzähne aus den Höhlen Nordwestkroatiens.- Paleontologia Jugoslavica, 36, 1-40.

Paunović, M., 1991: Morfometrijske karakteristike zubi vrste Ursus spelaeus iz gornjopleistocenskih slojeva Visoke Pećine kod Valjeva (Srbija).- Geološki vjesnik, 44, 49-53.

Pohar, V., Kralj, P., Rabeder, G. \& M. Mišič, 2002: Cave sediments and fossil mammal remains in Krizna jama, Southern Slovenia.- Abhandlungen der KarstHöhlenkunde, 34, 49-51.

Pohar, V. \& G. Rabeder, 2010: Brlog jamskego medveda.In: Kržič, M. (ed.) Križna jama, Društvo ljubiteljev Križne jame, pp. 36-37, Ljubljana.

Příhoda, K., Krs, M., Pešina, B. \& J. Bláha, 1989: MAVACS - a new system of creating a non-magnetic environment for paleomagnetic studies.- Cuadernos de Geología Ibérica, 12, 223-250.

Pruner, P., Bosák, P., Zupan Hajna, N., Mihevc, A., Man, O. \& P. Schnabl, 2004: Paleomagnetic research of cave sediments in Križna jama, Planinska jama and Postojnska jama: preliminary results (abs.).- In: $12^{\text {th }}$ International Karstological School, Classical Karst - Dating of Cave Sediments, Postojna. Guide booklet for the excursions and abstracts of presentations, 61-62, Postojna.

Rabeder, G., 1983: Neues von Höhlenbären. Zur Morphogenetik der Backenzähne.- Die Höhle, 34, 6785.

Rabeder, G., 1989: Modus und Geschwindigkeit der Höhlenbären-Evolution.- Schriften des Vereines zur Verbreitung naturwissenschaftlicher Kenntnisse, 127, 105-126.

Rabeder, G., 1999: Die Evolution des HöhlenbärenGebisses.- Mitteilung der Kommission für Quartärforschung der Österreichischen Akademie der Wissenschaften, 11, 1-102.

Rabeder, G., 2007: Evolution, Migration und Klimageschichte in den Alpen am Beispiel der Bären (Ursidae, Mammalia).- Denisia, 20, 745-752.

Rabeder, G., 2009: Die Höhlenbären der Krizna jama, Slowenian.- In: Hugo Obermaier-Gesselschaft $51^{\text {st }}$ Annual Meeting in Ljubljana, $14^{\text {th }}-18^{\text {th }}$ April 2009, Ljubljana. 57-58, Erlangen.

Rabeder, G., 2010: Jamski medvedi.- In: Kržič, M. (ed.): Križna jama, Društvo ljubiteljev Križne jame, pp. 34-35, Ljubljana.

Rabeder, G., Debeljak, I., Hofreiter, M. \& G. Withalm, 2008: Morphological responses of cave bears (Ursus spelaeus group) to high-alpine habitats.- Die Höhle, 59, 1-4, 59-72. 
Rabeder, G. \& M. Hofreiter, 2004: Der neue Stammbau der alpinen Höhlenbären.- Die Höhle, 55, 58-77.

Rabeder, G., Hofreiter, M., Nagel, D. \& G. Withalm, 2004: New Taxa of Alpine Cave Bears (Ursidae, Carnivora).- Cahiers scientifiques/Hors séries, 2, 49-67.

Rabeder, G. \& G. Withalm, 2001: The Križna jama near Lož in the classic karst.- In: $7^{\text {th }}$ International Symposium on Cave Bear, Excursion Guide, 1-4, Opicina.

Rakovec, I., 1956: Razvoj Pleistocena na Slovenskem.- In: Prvi jugoslovanski geološki kongres na Bledu 1954, 59-72, Ljubljana.

Rakovec, I., 1957: O jamskem medvedu.- Proteus, Ljubljana, 19, 265-272.

Rakovec, I., 1975: Razvoj kvartarne sesalske favne v Sloveniji (Über quartäre Säugetierfaunen Sloweniens (NW Jugoslawien).- Arheološki vestnik, 24, 225270.

Ryan, W.B.F., 1972: Stratigraphy of late Quaternary sediments in the Eastern Mediterranean.- In: Stanley, D.J. (ed.): The Mediterranean Sea: A natural Sedimentation Laboratory, Dowden, Hutchinson \& Ross, pp. 149-169, Stroudsberg.

Šerko, A. \& I. Michler, 1948: Postojnska jama in druge zanimivosti krasa.- $66 \mathrm{pp}$, Ljubljana.

Šerko, A. \& I. Michler, 1958: Die Grotte von Postojna (Adelsberger Grotte) und sonstige Sehenswürdigkeiten des Karstes.- Verlag des Unternehmens Postojnska jama (zweite, ergänzte Aflage; übersetzt von V. Bohinec), pp. 196, Ljubljana.

Shane, P., Black, T. \& J. Westgate, 1994: Isothermal plateau fission-track age for a paleomagnetic excursion in the Mamaku ignimbrite, New Zealand and implication for late Quaternary stratigraphy.- Geophysical Research Letters, 21, 16, 1695-1698.

Shaw, T.R., 1979: Križna jama, the earliest (?) published account.- Naše jame, 20, 59-62.

Schmidl, A., 1854: Die Grotten und Höhlen von Adelsberg, Lueg, Planina und Laas.- Wilhelm Braumüller, pp. 316, Wien.

Schmidl, A. A., 1863: Das Bihar-Gebirge an der Grenze von Ungarn und Siebenbürgen.- Förster \& Bartelmus, pp. 442, Wien.

Skoffiz A., 1847a: Reisenbilder eines Touristen. Zwei wenig besuchte Grotten in Krain.- Illyrisches Blatt. Zeitschrift für Vaterland, Kunst, Wissenschaft und geselliges Leben, 51, 26. Juni 1847, 201.

Skoffiz A., 1847b: Reisenbilder eines Touristen. 1. Bodlaser Grotte in Iunerkrain.- Illyrisches Blatt. Zeitschrift für Vaterland, Kunst, Wissenschaft und geselliges Leben, 52, 28. Juni 1847, 205-206.

Skoffiz A., 1847c: Reisenbilder eines Touristen.- Illyrisches Blatt. Zeitschrift für Vaterland, Kunst, Wissenschaft und geselliges Leben, 53, 3. Juli 1847, 209.
Skoffiz A., 1847d: Reisebilder eines Touristen.- Illyrisches Blatt. Zeitschrift für Vaterland, Kunst, Wissenschaft und geselliges Leben, 54, 6. Juli 1847, 213-214.

Smith, J.D. \& J.H. Foster, 1969: Geomagnetic reversal in Brunhes normal polarity epoch.- Science, 163, 565-567.

Soergel, W., 1940: Die Massenvorkommen des Höhlenbären. Ihre biologische und ihre stratigraphische Deutung.- Verlag von Gustav Fischer, pp. 112, Jena.

Szombathy, J., 1883: Die Höhlen und ihre Erfoschung.Verlag des Vereines zur Verbreitung naturwissenschaftlichen Kenntnisse Wien, 23, 487-526.

Tanaka, H., Turner, G.M., Houghton, B.F., Tachibana, T., Kono, M. \& M.O. McWilliams, 1996: Palaeomagnetism and chronology of the central Taupo Volcanic Zone, New Zealand.- Geophysical Journal International, 124, 919-934.

Thouveny, N., J. Carcaillet, J., Moreno, E., Leduc, G. \& D. Ne'rini, 2004: Geomagnetic moment variation and paleomagnetic excursions since $400 \mathrm{ka} \mathrm{BP}$ : A stacked record of sedimentary sequences of the Portuguese Margin.- Earth and Planetary Science Letters, 219, 377-396.

Wolf, B., 1939: Fossilium Catalogus, I: Animalia, pars 89. Fauna fossilis cavernarum II.- W. Junk B. V., 193240+97-208, Den Haag (reprint 1973 A. Asher \& Co. B. V., Vaals-Amsterdam).

Withalm, G., 2004: Analysis of the Cave Bear Metapodial Bones from Potočka zijalka (Slovenia).- Mitteilungen der Kommission für Quartärforschung der Österreichischen Akademie der Wissenschafften, 13, 149-160.

Zhu, R.X., Zhou, L.P., Laj, C., Mazaud, A. \& Z.L. Ding, 1994: The Blake geomagnetic polarity episode recorded in Chinese loess.- Geophysical Research Letters, 21, 8, 697-700.

Zörrer, J., 1838: Beschreibung einer Berghöhle Heiligen Kreuz unweit Laas in Adelsberger Kreise, nebst dem Grundrisse und Situations-Plane.- In: Hochenwart, Graf F. v. (ed.): Beiträge zur Naturgeschichte, Landwirthschaft und Topographie des Herzogthums Krain, 1, pp. 76-88, Laibach.

Zupan Hajna, N., Mihevc, A., Pruner, P. \& P. Bosák, 2008a: Cave Sediments from Postojnska-Planinska Cave System (Slovenia): Evidence of Multi-Phase Evolution in Epiphreatic Zone.- Acta carsologica, 37, 1, 63-86.

Zupan Hajna, N., Mihevc, A., Pruner, P. \& P. Bosák, 2008b: Paleomagnetism and Magnetostratigraphy of Karst Sediments in Slovenia.- Carsologica 8, Založba ZRC, pp. 266, Ljubljana. 